\title{
Energy damage index based on capacity and response spectra
}

\author{
S.A. Diaz ${ }^{1,3^{*}}$, L.G. Pujades ${ }^{1}$, A.H. Barbat ${ }^{2}$, Y.F. Vargas $^{1}$, D.A. Hidalgo-Leiva ${ }^{1}$
}

${ }^{1}$ Polytechnic University of Catalonia (UPC). DECA-ETCG. Barcelona Tech, Spain

${ }^{2}$ Polytechnic University of Catalonia (UPC). DECA-MMCE. Barcelona Tech, Spain

${ }^{3}$ Universidad Juárez Autónoma de Tabasco (UJAT). DAIA. Tabasco, México

\begin{abstract}
To assess the expected seismic damage of a structure, non-linear dynamic analysis and the damage index of ParkAng have been often used. Depending on the size of the structure and on the duration of the record, the computational effort in dynamic analyses is usually high. In this research a new damage index is proposed based on nonlinear static analysis. The damage index is a linear combination of two energy functions: 1) the strain energy associated to the stiffness variation and the ductility of the structure and 2) the energy dissipated associated to hysteretic cycles. These two energy functions are obtained from the capacity curve of the structure and from the energy balance with the spectral acceleration. To show the ability of the index to represent damage, low-rise steel buildings subjected to seismic actions expected in Mexico City are studied. The results obtained with the new method show a good agreement with those calculated by means of dynamic analyses using the Park-Ang damage index. In average, the Park-Ang damage index is well fitted by the combination of $62 \%$ of the strain energy and $38 \%$ of the energy dissipated by hysteresis. Moreover, this new damage index allows linking damage to certain characteristics of the seismic actions as, for instance, intensity and duration of the applied seismic action. Therefore, the new approach results in a practice and powerful tool for estimating the seismic damage in buildings, especially when considering probabilistic approaches, where massive computations are needed.
\end{abstract}

Keywords: Capacity curve; damage assessment; strain energy; energy dissipated by hysteresis; Monte Carlo simulations.

\section{Introduction}

When assessing the seismic performance of buildings, the Non Linear Dynamic Analysis (NLDA) has proved to be the most realistic, suitable, but also sophisticated, numerical tool which allows estimating the response of a structure as a function of time. When using the NLDA for assessing the seismic response, the input is, in general, a group of accelerograms, that can be recorded, synthetic or both. If the NLDA is performed by increasing the ordinates of the selected accelerograms, we are faced with the Incremental Dynamic Analysis (IDA) [1]. The use of IDA makes possible obtaining curves relating a measure of the seismic response of a structure (the roof displacement, the maximum inter story drift, etc.) to a variable which describes the seismic intensity like, for instance, the peak ground acceleration (PGA). The IDA has been used as the most appropriate tool for assessing the damage in structures subjected to dynamic actions [1]. It is important to note that, from the dynamic response of a structure, several damage indices can be calculated [2,3], which are related to the capacity reduction of the structural elements of 
buildings. Several investigations have proposed damage indices for reinforced concrete and steel buildings considering different parameters such as, for example, the displacement ductility [4,5], strength and stiffness degradation [3], energy dissipation [6,7], cyclic fatigue [8], change of the natural period of the structure [9], or a combination of the above parameters [10-13]. Most of the damage indices proposed up to date, take values in the range from 0 to 1, where 0 indicates no damage and 1 collapse. Park and Ang [11] proposed one of the most used seismic damage indices for reinforced concrete buildings that considers both the maximum structural response and the cyclic load effect [14-16].

For calculating damage curves based on IDA, an important computational effort is required. In order to avoid this large computational effort, the nonlinear static analysis (NLSA) offers an interesting alternative due to its simplicity $[17,18]$, but it is necessary to ensure that the obtained results are in good agreement with those provided by IDA. Several researchers have employed the NLSA for estimating parameters related to the dynamic response of structures [19-23] or in risk studies at urban level [24-27]. In the present article, a new damage index for steel buildings, which can be obtained from the capacity curve, is proposed. This damage index exhibits a good fit with the damage index of Park and Ang. The mathematical formulation of the new damage index is based on energy functions and on the idea proposed by Pujades et al. [22] of using a calibration parameter to determine the

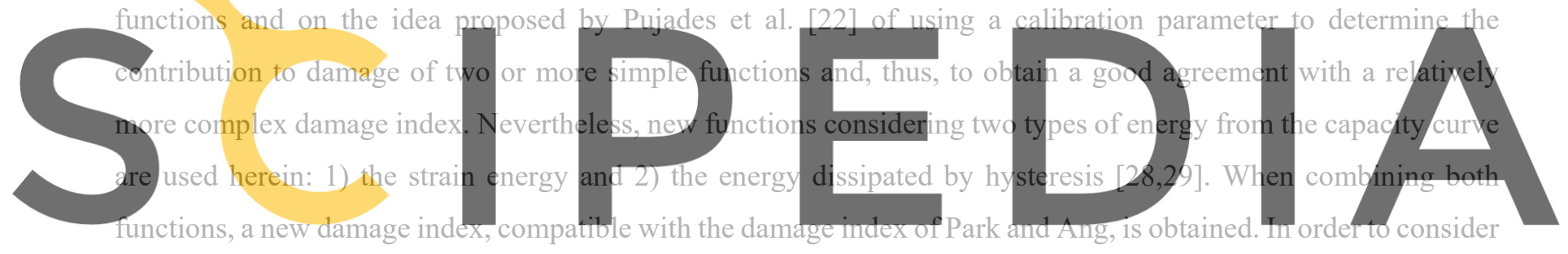

Register for free at https//WWW. fhcipedia.com to download the version without the watermark application the seismic evaluation is based on the study of Leelataviwat et al. [31]. As a testbed, a three stories

steel building, subjected to seismic actions expected in Mexico City, is employed. In order to formulate the new damage index, a deterministic case is presented first. A probabilistic approach based on the Monte Carlo method and on the Latin Hypercube Sampling (LHS) technique is also included. The cases studied in this article show that the new damage index for the steel structures typology analyzed herein allows assessing the expected damage directly from the capacity curve, in a straightforward way, thus avoiding the large of computational effort involved in dynamic simulations.

\section{Damage model based on energy}

\subsection{Damage index of Park and Ang}

The damage index of Park and Ang (PA) [11] allows estimating the damage level of structures starting from a postprocess of the nonlinear dynamic response; it is calculated as the sum of the maximum displacement divided by the ultimate displacement with a term related to the dissipated energy. For a structural element, the damage index, $\mathrm{DIe}_{\mathrm{PA}}$ $(\delta)$, is given by the following equation: 


$$
\operatorname{DIe}_{\mathrm{PA}}(\delta)=\frac{\delta}{\delta_{\mathrm{u}}}+\frac{\beta}{\mathrm{Q}_{\mathrm{y}} \delta_{\mathrm{u}}} \int_{0}^{\delta} \mathrm{dE}
$$

where $\delta / \delta_{\mathrm{u}}$ is the ductility defined as the ratio of the maximum displacement of the structural element subjected to a specific earthquake, $\delta$, to the ultimate displacement under monotonic loading, $\delta_{\mathrm{u}}$. Qy is the strength at the yielding point; if the strength, $\mathrm{Qu}$, corresponding to the ultimate displacement, $\delta \mathrm{u}$, is lower than Qy, then Qy is substituted by Qu. $\int_{0}^{\delta} \mathrm{dE}$ represents the hysteretic energy absorbed by the element during the earthquake and $\beta$ is a non-negative strength deteriorating parameter. The global damage index of a structure is obtained by calculating the weighted damage index, $\mathrm{DI}_{\mathrm{PAw}}(\delta)$. The following equation was proposed by Park and Ang [11] in order to calculated the $\operatorname{DI}_{\mathrm{PAW}}(\delta)$ :

$$
\operatorname{DI}_{\mathrm{PAw}}(\delta)=\sum_{\mathrm{i}=1}^{\mathrm{N}} \lambda_{\mathrm{i}} \mathrm{DIe}_{\mathrm{PA}}(\delta)_{\mathrm{i}}
$$

where DIe $\mathrm{PA}_{\mathrm{A}}(\delta)_{\mathrm{i}}$ is the damage index of the structural element I as defined in equation (1); $\mathrm{N}$ is the number of the damaged elements and $\lambda_{\mathrm{i}}$ is the ratio of the energy dissipated by hysteresis in the element $\mathrm{i}$ to the total hysteretic energy dissipated in the entire structure. Values of the damage index higher than 1.0 indicate structural collapse. In

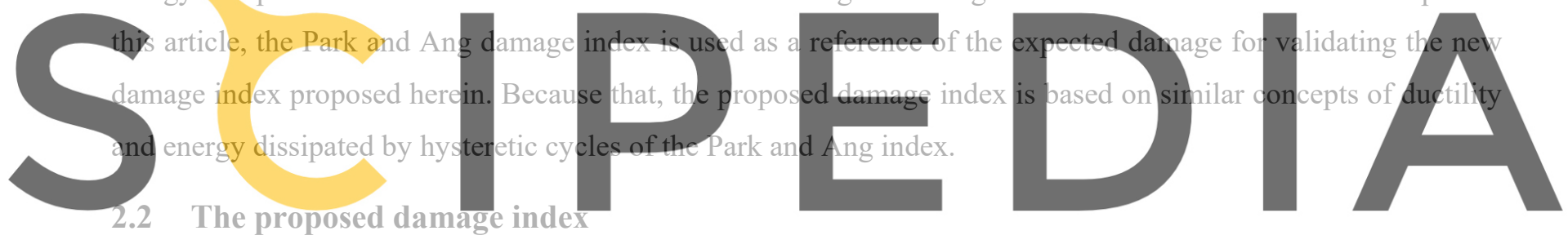

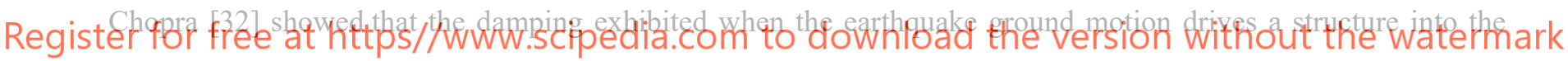 inelastic range can be viewed as a combination of the viscous damping, inherent to the structure, and the hysteretic} damping. Hysteretic damping is related to the area inside the loops defined by earthquake force - structurai displacement diagrams. Hysteretic damping can be represented as equivalent viscous damping, $\xi_{\text {eq }}$, associated with a maximum displacement and it can be estimated by means of the following equation [32]:

$$
\xi_{\mathrm{eq}}=\frac{1}{4 \pi} \frac{\mathrm{E}_{\mathrm{D}}}{\mathrm{E}_{\mathrm{so}}}
$$

where $\mathrm{E}_{\mathrm{so}}$ is the maximum strain energy associated to a cycle of motion, that is, the area under the secant stiffness at the ultimate point $\left(\mathrm{D}_{\mathrm{ci}}, \mathrm{F}_{\mathrm{ci}}\right)$ of the capacity curve, which can be calculated as:

$$
\mathrm{E}_{\mathrm{so}}=\frac{(\mathrm{Dci} * \mathrm{Fci})}{2}
$$

$E_{D}$ is the energy dissipated by the structure in a single cycle of motion, that is, in a single hysteretic loop. A graphic representation of $E_{D}$ and $E_{s o}$ is show in 
Figure 1. $E_{D}$ can be calculated starting from the bilinear representation of the capacity curve as the area enclosed within a single hysteretic loop, equivalent to the area of the large parallelogram shown in

Figure 1. The bilinear representation is obtained as follows: i) the area under the bilinear curve must be equal to the area under the original capacity curve, Ac; ii) the initial slope, Ki, must be equal in both curves and iii) the coordinates of the ultimate capacity point $\left(\mathrm{D}_{\mathrm{ci}}, \mathrm{F}_{\mathrm{ci}}\right.$ and $\left.\mathrm{D}_{\mathrm{bi}}, \mathrm{F}_{\mathrm{bi}}\right)$ must match both curves. Based on the later conditions the following equations can be uses for calculating the coordinates of the yield point (Dy, Fy):

$$
\begin{gathered}
\mathrm{D}_{\mathrm{y}}=\frac{2 \mathrm{Ac}-\left(\mathrm{F}_{\mathrm{ci}} * \mathrm{D}_{\mathrm{ci}}\right)}{\left(\mathrm{K}_{\mathrm{i}} * \mathrm{D}_{\mathrm{ci}}\right)-\mathrm{F}_{\mathrm{ci}}} \\
\mathrm{F}_{\mathrm{y}}=\left(\mathrm{K}_{\mathrm{i}} * \mathrm{D}_{\mathrm{y}}\right)
\end{gathered}
$$

Starting from the points defined by the bilinear curve, $\mathrm{E}_{\mathrm{D}}$ is calculated by using the following equation $[28,32]$ :

$$
\mathrm{E}_{\mathrm{D}}=4\left(\mathrm{~F}_{\mathrm{y}} * \mathrm{D}_{\mathrm{bi}}-\mathrm{D}_{\mathrm{y}} * \mathrm{~F}_{\mathrm{bi}}\right)
$$

Capacity curve

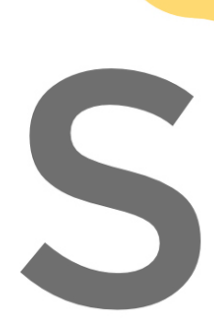

- Bilinear curve

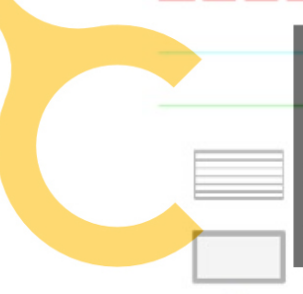

Dy, Fy

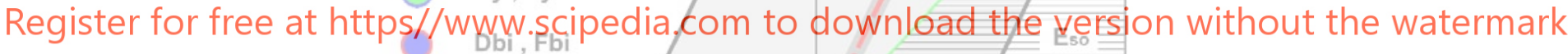

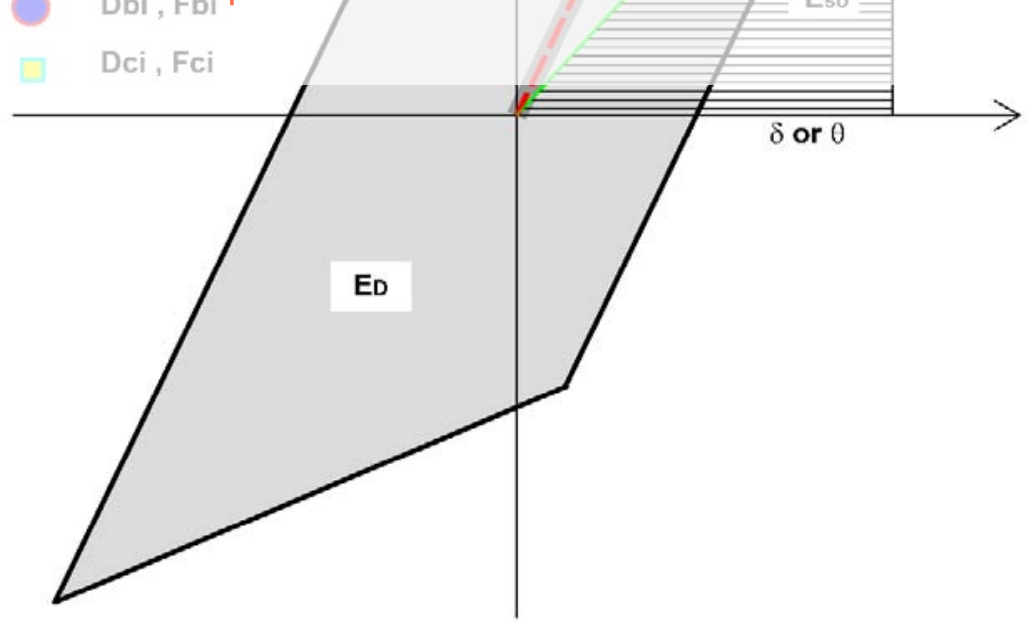

Figure 1 Capacity curve, bilinear curve (force-deformation relation) and equivalent viscous damping due to hysteretic energy dissipation. 
Note that $E_{s o}$ and $E_{D}$ can be calculated from the capacity curve as a function of the roof displacement, $\delta$, in an incremental manner. Thus, two energy functions are defined as follows: 1$)$ strain energy function, $\mathrm{E}_{\mathrm{so}}(\delta)$ and 2 ) energy dissipated by hysteretic function, $\mathrm{E}_{\mathrm{D}}(\delta)$. Based on the mathematical development of Chopra [32] for $\mathrm{E}_{\mathrm{so}}(\delta)$ and $\mathrm{E}_{\mathrm{D}}(\delta)$, the former can be related to the stiffness and ductility and the latter to the energy dissipation; both functions depend on the intensity of the earthquake.

Based on these functions, a damage index can be derived adopting two following the criteria: i) Both functions are normalized to 1 for the value related to the ultimate displacement, $\delta \mathrm{u}$, of the capacity curve; ii) both functions will have a value equal to zero for $\delta \leq \delta_{\text {Dy }}$ because, within the linear range of the structure, the expected damage should be zero. Thus, the normalized energy functions $\mathrm{E}_{\mathrm{so}}(\delta)_{\mathrm{NN}}$ and $\mathrm{E}_{\mathrm{D}}(\delta)_{\mathrm{NN}}$ can be calculated by means of the following

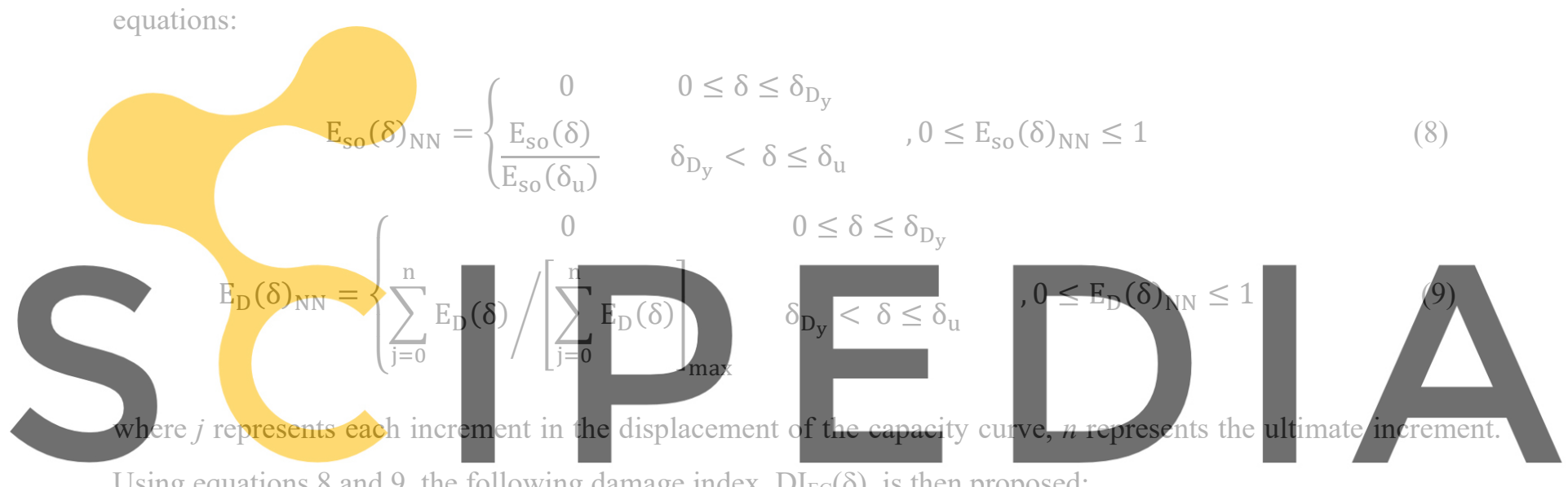

Using equations 8 and 9 , the following damage index, $\operatorname{DI} \mathrm{ICC}_{\mathrm{EC}}(\delta)$, is then proposed:

Register for free at https//Myww:scipedia.com to download the version without the watermark

Observe that DipAw $(\delta)$ can be used to calibrate the value of the parameter $\eta$. The parameter $\eta$ is directiy related to the percentage of the contribution to the damage of the strain energy function, while their counterpart in Eq.10, corresponds to the contribution of the energy dissipated due to the hysteretic function. The two energy functions can be obtained from the capacity curve of the building; although, can also be obtained from the bending moment M rotation $\theta$ curve of a structural element; and $\operatorname{DIe}_{\mathrm{PA}}(\delta)$ is used to calibrate the value of the parameter $\eta$. This new damage index is referred hereinafter as energy capacity damage index, $\mathrm{DI}_{\mathrm{EC}}(\delta)$. The calculation and implementation of $\mathrm{DI}_{\mathrm{EC}}(\delta)$ are presented in the next section.

\section{Example of implementation the new damage index}

\subsection{Structural model}

A three stories steel building with four spans is used to illustrate the computation of the proposed energy capacity damage index. This building has been studied extensively by Diaz et al. [33] in order to study its performance and its expected seismic damage for the Mexico City conditions. The main geometric characteristics and structural 
sections of the building are show in Figure 2. The structural system of the building is a special moment frame (SMF) composed of beams and columns with $\mathrm{W}$ sections (American wide flange section), which are joined by means of prequalified connections [34] type Fully Restrained (FR). This building was designed as an office building considering the provisions of NTC-DF [35] and ANSI/AISC 341-10 [36]. The design of the SMFs satisfies the criterion of strong column-weak beam. The nonlinear structural analyses, both static and dynamic, were performed using Ruaumoko 2D software [2]. Beams and columns were modeled as FRAME type members, with plastic hinges at their ends. Plastic hinges follow the Bi-Linear Hysteresis rule with hardening and strength reduction based on its ductility factor. See Appendix A - Ruaumoko 2D [2]. Due to the limitations of the adopted model, which only reproduces the failure by bending moment, the interaction between moment and axial force is not considered. In addition, most of the damage for this type of building is expected to occur at the ends of the elements, mainly because of the effects of the bending moment. The interaction of yield surface is defined for columns and beams by the diagram relating the bending-moment with the rotation. Moreover, the values of strength and ductility for the hysteresis rule were calculated according to the modified Ibarra-Medina-Krawinkler (IMK) model [37-39]. The panel zones were modeled by using the rotational stiffness in connections, according to the model of Krawinkler [40] included in FEMA 355C [41]. For the damping, it is assumed the Rayleigh model and a damping ratio of 2\%
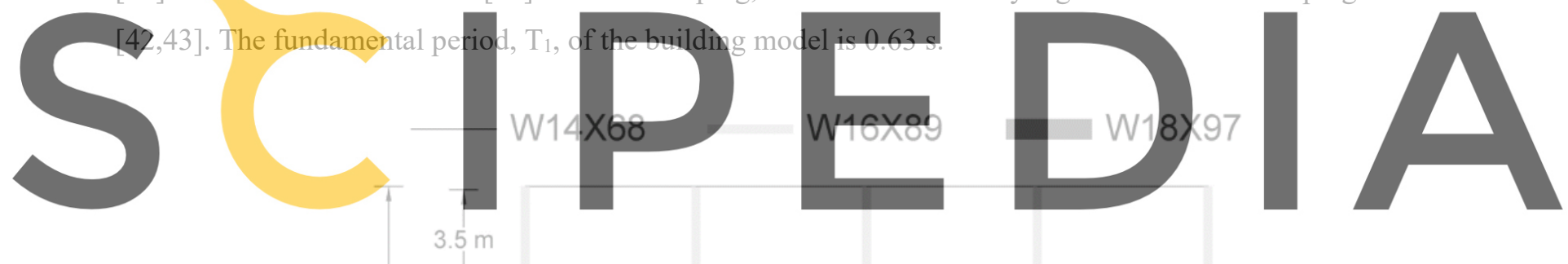

Register for free at https//www.scipedia.com to download the version without the watermark

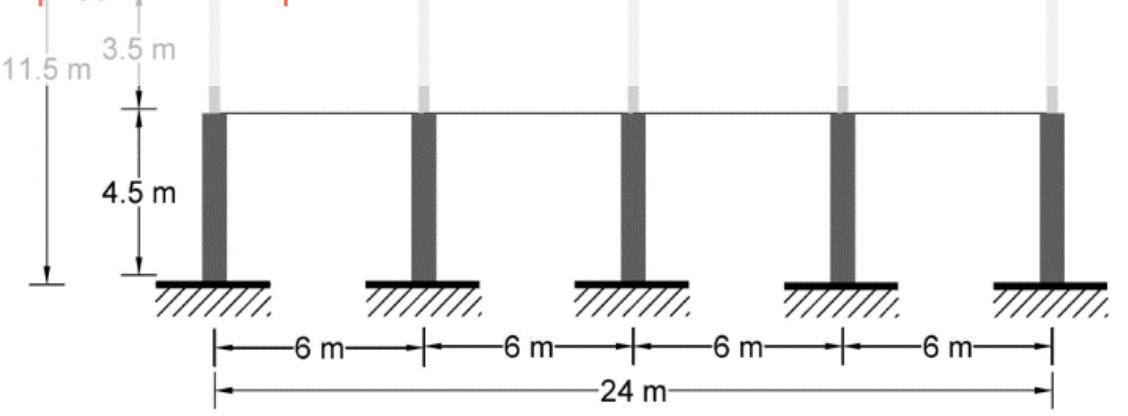

Figure 2 Geometry and structural section of the archetype building.

\subsection{Seismic actions}

In order to calibrate the new damage index, $\operatorname{DI}_{\mathrm{EC}}(\delta)$, it is necessary to obtain damage curves using the IDA method. Acceleration records of Mexico City were used in this example. The design spectrum for the IIIa seismic area, according to NTC-DF [35], was taken as target spectrum. The selection method proposed by Vargas et al. [21] was applied to a database that contains 2554 accelerograms recorded in the Mexico City area [44]. Four accelerograms 
were thus selected whose response spectra are compatible, in mean, with the target spectrum. The main characteristics of these accelerograms are shown in Table 1.

Table 1-Characteristic of the seed accelerograms used of the seismic zone IIIa in Mexico City.

\begin{tabular}{|c|c|c|c|c|c|c|c|c|c|c|c|}
\hline \multirow{2}{*}{ Acc. } & \multirow{2}{*}{ Station } & \multirow{2}{*}{ Date } & \multirow{2}{*}{$\begin{array}{l}\text { Duration } \\
\text { (seconds) }\end{array}$} & \multicolumn{3}{|c|}{ Epicenter } & \multirow{2}{*}{$\begin{array}{l}\text { Magnitude } \\
\text { (Mw) }\end{array}$} & \multirow{2}{*}{ Component } & \multirow{2}{*}{$\begin{array}{l}\text { PGA } \\
(\mathrm{cm} / \mathrm{s} 2)\end{array}$} & \multirow{2}{*}{$\begin{array}{c}\text { Epicenter } \\
\text { distance } \\
(\mathrm{km})\end{array}$} & \multirow{2}{*}{$\begin{array}{l}\text { Azimut } \\
\text { Station- } \\
\text { Epicenter }\end{array}$} \\
\hline & & & & Latitude & Longitude & $\begin{array}{l}\text { Depth } \\
(\mathrm{Km})\end{array}$ & & & & & \\
\hline 1 & AL01 & $18 / 04 / 2014$ & 165.77 & $17.18 \mathrm{~N}$ & $101.19 \mathrm{~W}$ & 10 & 7.2 & S00E & 28.86 & 330.89 & 221.04 \\
\hline 2 & HJ72 & $18 / 04 / 2014$ & 167.47 & $17.18 \mathrm{~N}$ & $101.19 \mathrm{~W}$ & 10 & 7.2 & N90W & 32.19 & 331.06 & 221.39 \\
\hline 3 & MJSE & $15 / 06 / 1999$ & 144.01 & $18.18 \mathrm{~N}$ & $97.51 \mathrm{~W}$ & 69 & 7.0 & N76W & 13.76 & 222.31 & 128.79 \\
\hline 4 & TL55 & 30/09/1999 & 173.86 & $15.95 \mathrm{~N}$ & $97.03 \mathrm{~W}$ & 16 & 5.2 & N90E & 15.62 & 447.59 & 149.67 \\
\hline
\end{tabular}

Each one of the accelerograms of Table 1 was used as a seed within a probabilistic spectral matching technique $[33,45]$ to get 5 new accelerograms whose response spectra show a good agreement with the target spectra. Thus, a set of 20 matched accelerograms were obtained, considered suitable to deal with the uncertainties in the seismic actions in order to validate the proposed damage index in a probabilistic environment. Figure 3a shows the seed
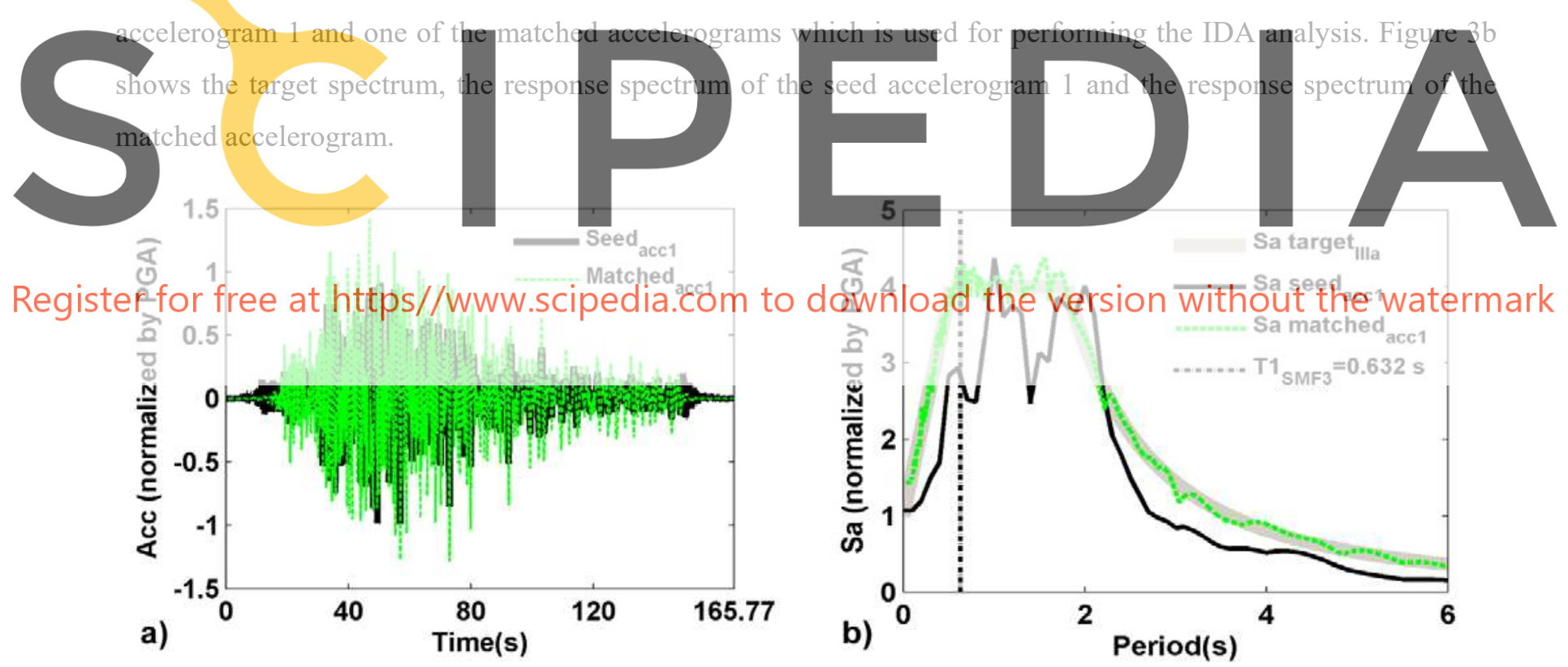

Figure 3 a) The seed accelerogram 1 and the matched accelerogram, and b) the target spectrum (IIIa) and the response spectra for seed accelerogram 1 and the matched accelerogram.

\subsection{Capacity curve}

The capacity curve is obtained by means of an adaptive pushover analysis $\left(\mathrm{P}_{\mathrm{ad}}\right)$, implemented in the Ruaumoko software [2]. This method is independent of the initial loading pattern as the method adapts this pattern at each step of the $\mathrm{P}_{\mathrm{ad}}$ according to the shape of the first vibration mode of the structure. The ultimate capacity is set when one of the following criteria is fulfilled: i) $\omega^{2}$ is less than $10^{-6} \omega^{2}$ at the first step, being $\omega$ the tangent fundamental 
natural frequency in the Modified Rayleigh Method; ii) the Newton Raphson iteration is not achieved within a maximum number of specified cycles; iii) the stiffness matrix becomes singular and iv) a specified maximum structure displacement is reached. In the NLSA's of the studied models, a large number of cycles for the Newton Raphson method has been considered. Moreover, a large maximum limit for the structure displacement has been considered too; thus, it is expected that the failure criteria be related to criteria $\mathrm{i}$ or iii. The conventional pushover and the $\mathrm{P}_{\mathrm{ad}}$ for buildings with structural response dominated by their fundamental mode provide similar capacity curves; however, in this research, the $\mathrm{P}_{\mathrm{ad}}$ is preferred, because it includes predefined criteria to determine the ultimate capacity point, previously mentioned. Which is useful in the probabilistic assessments to define the collapse in each analysis. In addition, these predefined failure criteria in the capacity curve allow obtained a compatibility with the ultimate capacity point achieved the IDA. Moreover, for the methodology presented in this study, the conventional pushover can also be used, if the ultimate capacity point is adequately defined. Figure $4 \mathrm{a}$ shows the plastic hinges formed in the ultimate capacity point of the building and in the Figure $4 \mathrm{~b}$ its respective inter-story drift. The size of each plastic hinges in the building corresponds to the degree of plasticization in each structural element, when the building reaches its ultimate capacity. Finally, in the Figure 5a shows the obtained capacity curve.

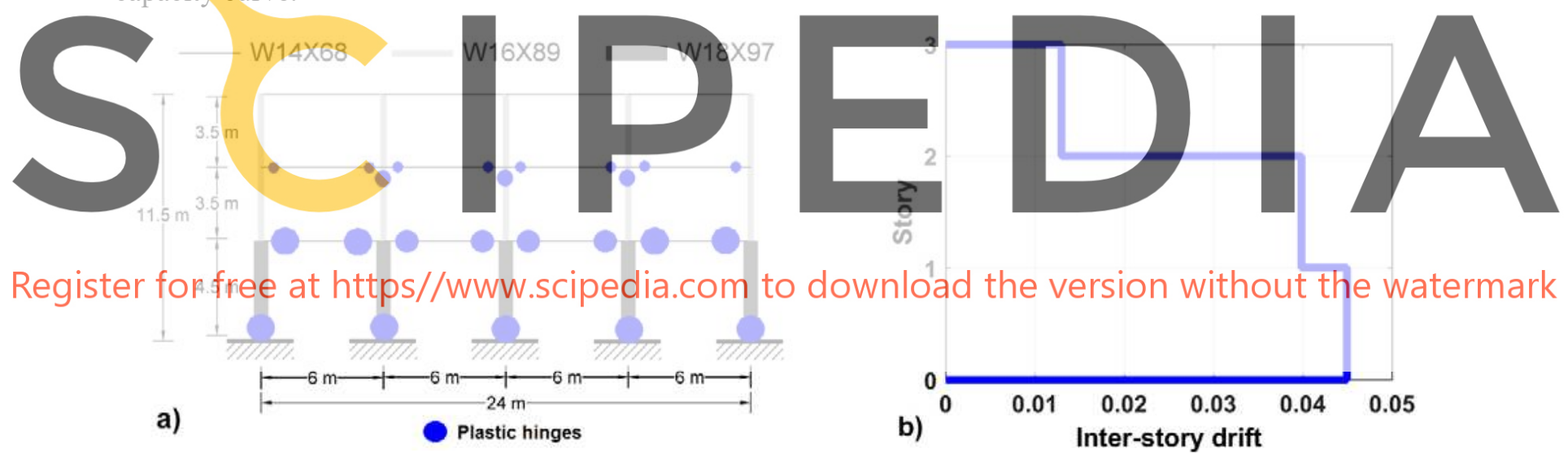

Figure 4 a) Plastic hinges formed when the building reaches its ultimate capacity and b) its respective inter-story drift.

\subsection{Incremental dynamic analysis}

The incremental dynamic analysis is performed for the studied building using the matched accelerogram shown in Figure 3a. The PGA of the record has been increased until the collapse of the structure, established in terms of ultimate displacement $\delta_{\mathrm{u}}$, was reached. The collapse displacement of the building, in this case, corresponds to a PGA of $1 \mathrm{~g}$. The $\operatorname{DI}_{\mathrm{PAw}}(\delta)$ function of the roof displacement, $\delta$, for the building is shown in Figure 5a. The capacity curve and the $\mathrm{DI}_{\mathrm{PAw}}(\delta)$ are used in subsequent sections for calibrating the new damage index.

In order to prove that the new damage index can also be applied to a structural element, having the results of the IDA for the building, one can extract: i) the relation between $\operatorname{DIe}_{\mathrm{PA}}(\theta)$ and the rotation $\theta$, ii) the bending moment 
$\mathrm{M}$ - rotation $\theta$ curve of one of the beams on the first floor in the building, that is referred hereinafter BEAM 1 and shown in the Figure $5 b$.
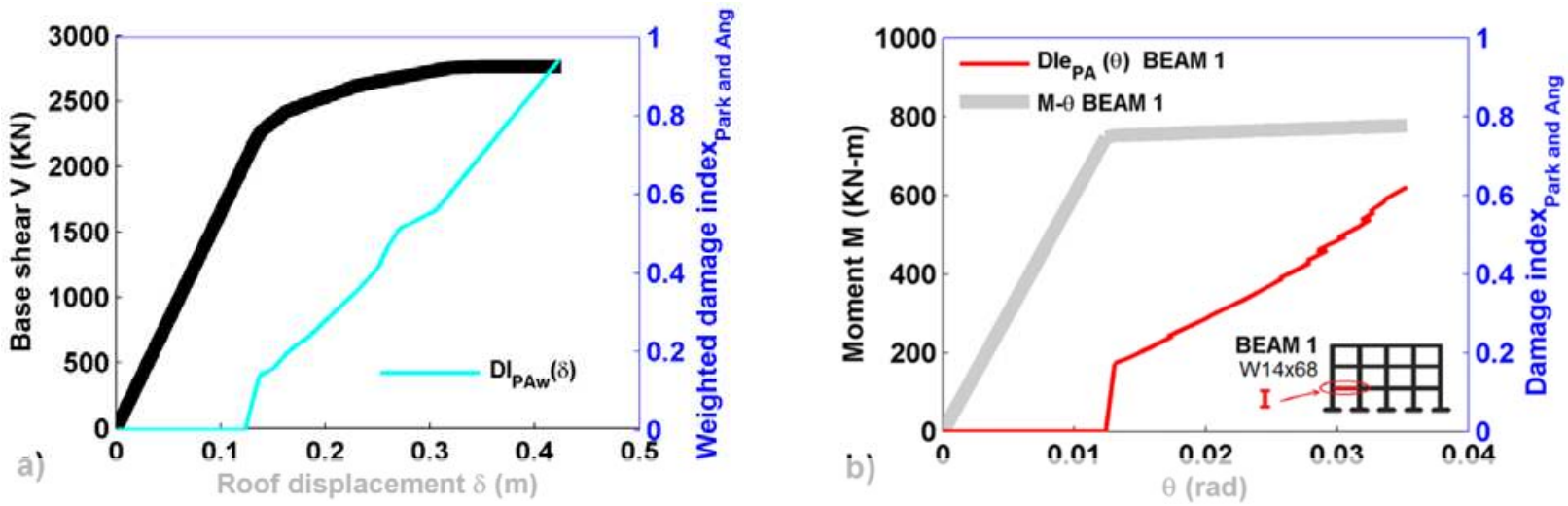

Figure 5 a) Capacity curve and the $\operatorname{DIPAw}_{\mathrm{PA}}(\delta)$ by IDA of the building; and b) the $\mathrm{DI} \mathrm{ePA}_{\mathrm{PA}}(\theta)$ and M- $\theta$ diagram of the BEAM 1.

\subsection{Proposed energy damage index for a structural element}

As a first step, the damage index for a structural element is implemented, so that it can be calibrated with $\operatorname{DIe}_{\mathrm{PA}}(\theta)$.

This is done for the structural element, BEAM 1. Based on the M- $\theta$ curve, the two energy functions depending on
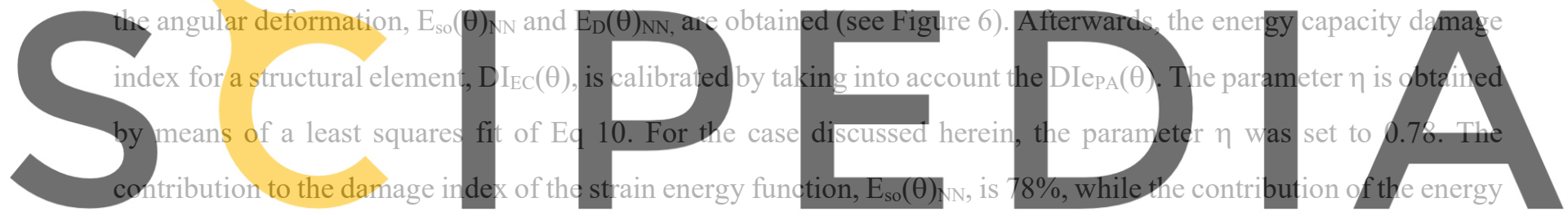

dissipated by hysteretic, $\mathrm{E}_{\mathrm{D}}(\theta)_{\mathrm{NN}}$, is $22 \%$. Figure 6 shows the $\operatorname{DIepA}_{\mathrm{PA}}(\theta)$ and $\operatorname{DI} \operatorname{IC}_{\mathrm{EC}}(\theta)$ for the $\operatorname{BEAM} 1$. The $\operatorname{DI}_{\mathrm{EC}}(\theta)$

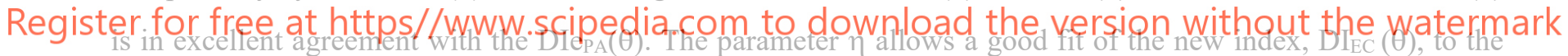

expected damage in a structural element subjected to seismic actions.

This example shows that the proposed functions and damage index can replicate the expected damage in the element structural by the Park and Ang index. However, for that, the proposed index can be a viable alternative to reduce the computational times in the probabilistic assessments; this should be calculated directly from the capacity curve, as shown in the next section. 


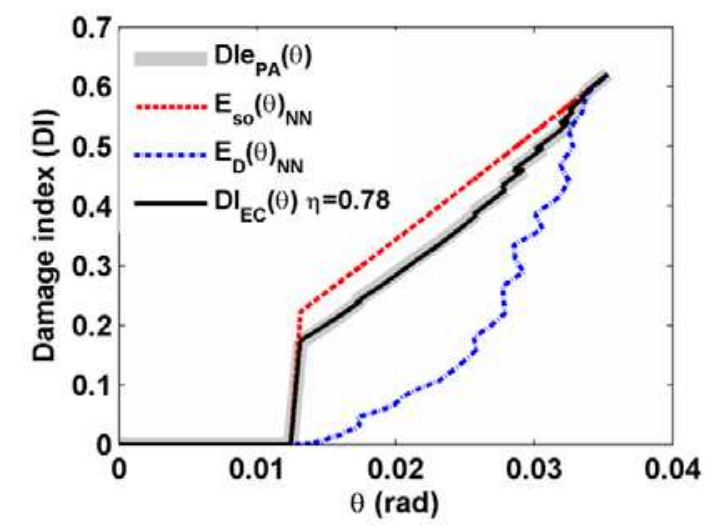

Figure 6 New damage index of $\operatorname{DIe}_{\mathrm{EC}}(\theta)$ and $\operatorname{DI}_{\mathrm{PA}}(\theta)$ for the BEAM 1.

\subsection{Energy capacity dlamage index for the entire building}

In order to calibrate the simplified energy capacity damage index $\operatorname{DI}_{\mathrm{EC}}(\delta)$, it is considered that the evolution of the damage $\operatorname{DI}_{\text {PAw }}(\delta)$ is closely related to the roof displacement caused by the seismic action. Observe that it is expected that these displacements be different for different seismic actions because important properties as, for instance, the duration and frequency content of each seismic action can vary, causing a different structural response for equal

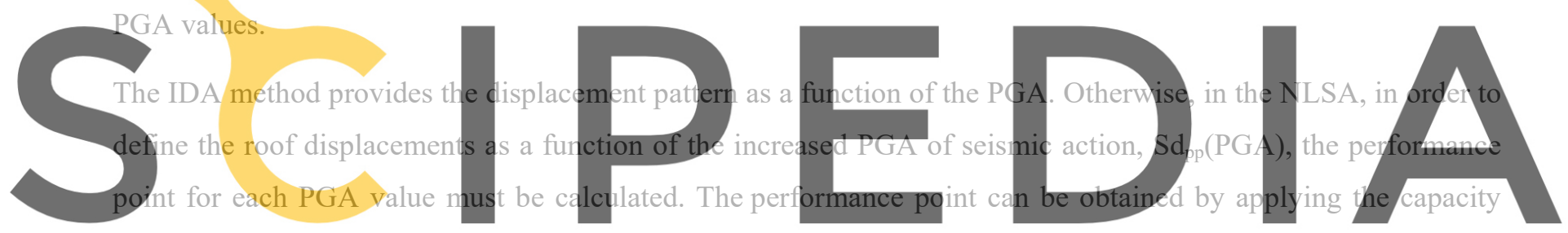

spectrum method proposed by Freeman [46] and included in ATC-40 [28], FEMA-273 [47]. Chopra and Goel [29]

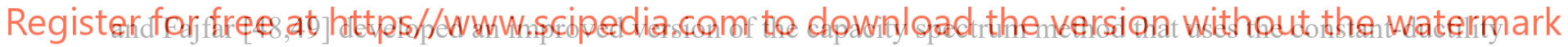

design spectrum as demand diagram. In these researches, the concepts of equivalent ductility factors by the $\mathrm{R}_{\mathrm{y}}-\mu_{\mathrm{s}^{-}}$

T equations introduced by Newmark and Hall [50] and Vidic et al. [51] are used, where $\mathrm{R}_{\mathrm{y}}$ is the reduction factor due to the ductility, $\mu_{\mathrm{s}}$ is the ductility factor defined as the ratio between the maximum displacement and the yield displacement and $\mathrm{T}$ is the period of the demand spectrum. Another proposal for calculating the performance point is that of Mezzi et al. [52] and Leelataviwat et al. [31,53], which is based on the balance between the energy spectrum of the seismic action in the Energy Displacement Response Spectrum (EDRS) format and the energy obtained from the area beneath the capacity curve, named as Accumulated Deformation Energy, ADE. In the present research, the methodology of energy balance is used to obtain the displacement patterns due to seismic actions. In this methodology, the capacity curve obtained from the building, shown in Figure 5a, and the response spectrum of the acceleration shown in Figure 3b, have been used.

The first step for calculating the performance point consists in obtain the accumulated deformation energy, ADE, of the capacity curve, $F(\delta)$, by using the a following equation: 


$$
\operatorname{ADE}(\delta)=\int_{0}^{\delta} \mathrm{F}(\xi) \mathrm{d} \xi \quad 0 \leq \xi \leq \delta_{\mathrm{u}} ; \quad 0 \leq \operatorname{ADE}(\delta) \leq \operatorname{ADE}\left(\delta_{\mathrm{u}}\right)
$$

Figure 7 shows the capacity curve and the $\operatorname{ADE}(\delta)$ curve of the building. The yielding roof displacement, $\delta_{\mathrm{y}}$, the yielding base shear, $\mathrm{V}_{\mathrm{y}}$, and the yielding energy $\mathrm{E}_{\mathrm{y}}$ are also plotted in this figure. The second step consists in obtaining the input energy spectrum in EDRS format $\left(\mathrm{Sa}_{\mathrm{EDRS}}\right)$ from the pseudo-velocity spectrum, $\mathrm{Sv}$, using the following equation:

$$
\begin{aligned}
\operatorname{Sa}_{\mathrm{EDRS}} & =\frac{1}{2} \gamma_{\mathrm{E}} \mathrm{M}^{*} \mathrm{~Sv}^{2}=\frac{1}{2} \gamma_{\mathrm{E}} \mathrm{M}^{*} \mathrm{Sa}^{2}\left(\frac{\mathrm{T}}{2 \pi}\right)^{2} \\
\gamma_{\mathrm{E}} & =\frac{\mu_{\mathrm{E}}}{\mathrm{R}_{\mathrm{y}}{ }^{2}} ; \quad \mu_{\mathrm{E}}=2 \mu_{\mathrm{s}}-1
\end{aligned}
$$

where $M^{*}$ is the effective modal mass for the first mode of vibration of the building; $T$ is the period of the demand spectrum; $\mu_{\mathrm{s}}$ is the ductility factor; $\gamma_{\mathrm{E}}$ is the energy factor, in terms of energy ductility $\mu_{\mathrm{E}} ; \mathrm{R}_{\mathrm{y}}$ is the yield strength reduction factor; and $\mathrm{Sa}$ is the pseudo-acceleration spectrum. The values of $\mu_{\mathrm{s}}$ and $\mathrm{R}_{\mathrm{y}}$ can be easily obtained by using $\mathrm{R}_{\mathrm{y}}-\mu_{\mathrm{s}}-\mathrm{T}$ equations evaluable in the literature [29]. In this research, the equations proposed by Chopra [32] based on the elastic design spectrum of Newmark and Hall [50] have been used:

$$
\mathrm{R}_{\mathrm{y}}=\left\{\begin{array}{cc}
1 & \mathrm{~T}<\mathrm{T}_{\mathrm{a}} \\
\left(2 \mu_{\mathrm{s}}-1\right)^{\frac{\beta^{*}}{2}} & \mathrm{~T}_{\mathrm{a}} \leq \mathrm{T} \leq \mathrm{T}_{\mathrm{b}} \\
\sqrt{2 \mu_{\mathrm{s}}-1} & \mathrm{~T}_{\mathrm{b}} \leq \mathrm{T} \leq \mathrm{T}_{\mathrm{c}} \sqrt{2 \mu_{\mathrm{s}}-1} / \mu \\
\left(\mathrm{T} / \mathrm{T}_{\mathrm{c}}\right) \mu_{\mathrm{s}} & \mathrm{T}_{\mathrm{c}} \sqrt{2 \mu_{\mathrm{s}}-1} / \mu \leq \mathrm{T} \leq \mathrm{T}_{\mathrm{c}} \\
\mu_{\mathrm{s}} & \mathrm{T}>\mathrm{T}_{\mathrm{c}} \\
\beta^{*}=\ln \left(\frac{\mathrm{T}}{\mathrm{T}_{\mathrm{a}}}\right) \ln \left(\frac{\mathrm{T}_{\mathrm{a}}}{\mathrm{T}_{\mathrm{b}}}\right)
\end{array}\right.
$$

where $\mathrm{Ta}, \mathrm{Tb}$ and $\mathrm{Tc}$ are limiting period values that depend on ground motion parameters. Based on the demand spectrum in the Acceleration Displacement Response Spectrum (ADRS) format and by using the Eqs. (12) to (15), the $\mathrm{Sa}_{\mathrm{EDRS}}$ can be obtained. 


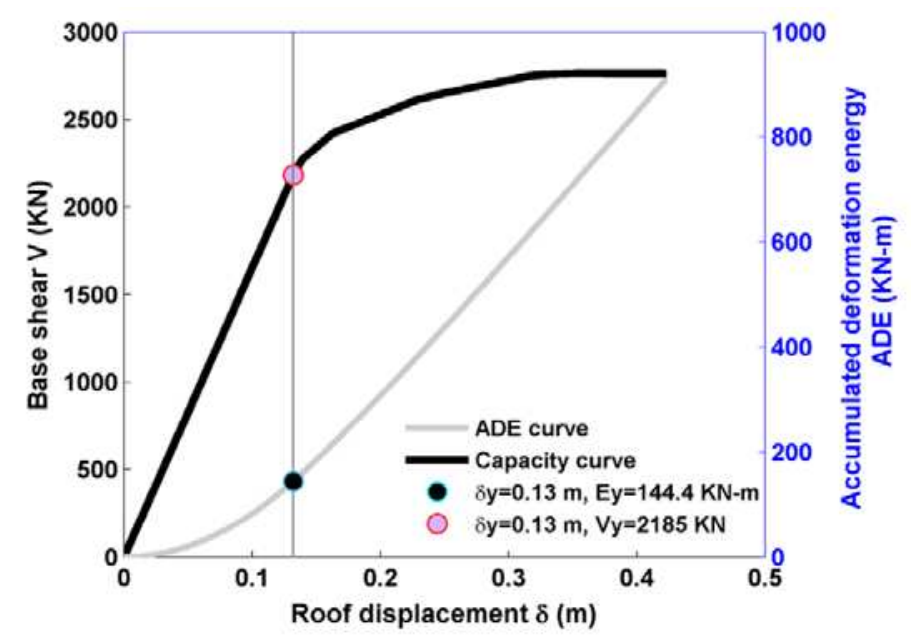

Figure 7 Capacity curve and ADE curve of the building.

In order to assure the energy balance [31,52-54], the following steps should be carried out: i) convert the displacement at the roof of the ADE curve to spectral displacement, Sd, by using the modal participation factor, $\mathrm{PF}_{1}$; ii) normalize the ADE curve and the spectrum of energy demand, SaEDRS, with the corresponding energy value at the yielding displacement, $\mathrm{E}_{\mathrm{y}}$; iii) obtain the SaEDRs for a ductility, $\mu \mathrm{s}=1$, and cross $\mathrm{Sa}_{\mathrm{EDRS}}$ and $\mathrm{ADE}$ curves to find the performance point $\mathrm{Sd}_{\mathrm{PP}}$; iv) determine the ductility $\mu_{\mathrm{PP}}$ of the relation $\mathrm{Sd}_{\mathrm{PP}}$ with the yielding spectral displacement $\mathrm{Sd}_{\mathrm{y}}$; if $\mu_{\mathrm{PP}} \leq 1$, then the $\mathrm{Sd}_{\mathrm{PP}}$ is the displacement of performance for the seismic action applied and the structure has a performance in the linear range; if $\mu_{\mathrm{PP}}>1$, perform again the step iii) for a higher $\mu$ s and determine a new $\operatorname{Sd}_{\mathrm{PP}}$ and $\mu_{\mathrm{PP}}$; repeat until $\mu \mathrm{s} \approx \mu_{\mathrm{PP}}$ with a predefined error; then the new $\operatorname{Sd}_{\mathrm{PP}}$ is the displacement of performance for the seismic action applied and the structure has a performance in the nonlinear range. Finally, convert $\mathrm{Sd}_{\mathrm{PP}}$ to roof displacement $\delta$, by using the modal participation factor, $\mathrm{PF}_{1}$.

For the studied case, $\mathrm{M}^{*}=215.5 \mathrm{KN} \mathrm{sec} / \mathrm{m}, \delta_{\mathrm{y}}=0.13 \mathrm{~m} ; \mathrm{E}_{\mathrm{y}}=144.4 \mathrm{KN}-\mathrm{m}, \mathrm{PF}_{1}=1.29$, the $\mathrm{R}_{\mathrm{y}}-\mu \mathrm{s}-\mathrm{T}$ are taken from Eqs (14) and (15) where $\mu \mathrm{s}=1, \mathrm{Ta}=1 / 33 \mathrm{~s}, \mathrm{~Tb}=0.125 \mathrm{~s}$ and $\mathrm{T} \mathrm{c}=0.6 \mathrm{~s}$ defined by Chopra [32]. The Sa matched acc1 for a PGA equal to $0.45 \mathrm{~g}$ shown in Figure $8 \mathrm{a}$ is used. Figure $8 \mathrm{~b}$ shown the respective Sa matched acc1 in EDRS format and normalized to $\mathrm{E}_{\mathrm{y}} \mathrm{T} \mathrm{Ta}, \mathrm{Tb}$ and $\mathrm{Tc}$ used in the Ry-Mu-T equations, for the particular case studied, have provided adequate results, this is attributed to that, Ry becomes in constant in the Ry-Mu-T equations for medium and long periods, so that, its variation affects structures of short periods. Then for the case studied, that have a medium period $(\mathrm{T} 1=0.63 \mathrm{~s})$, the variation of Ry does not have an important influence on the application of the energy balance. However, this may not be the case with other seismic actions and types of buildings, so it is recommended calibrate these boundary periods for each case. 

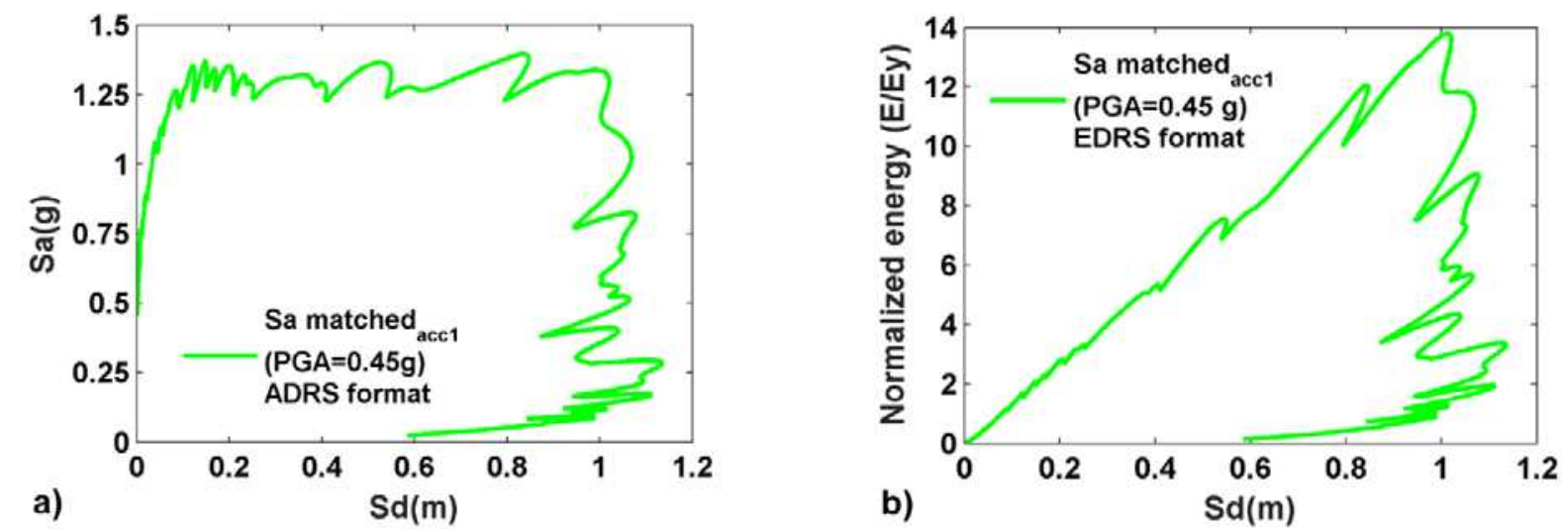

Figure $8 \mathrm{Sa}$ matched acc1 for a PGA equal to $0.45 \mathrm{~g}$ in a) ADRS format and b) EDRS format.

Figure 9a shows an example of the energy balance for the building by using $\mathrm{Sa}_{\text {matched }}$ acc $1_{\text {(EDRS format) }}$ for a PGA=0.45 $\mathrm{g}$ and the ADE curve shown in Figure 7; both curves are normalized to $\mathrm{E}_{\mathrm{y}}$. For the considered values $\mathrm{Sd}_{\mathrm{pp}}=0.17 \mathrm{~m}$ and $\mu_{\mathrm{s}}=1.64$.

The static roof displacements are then determined assuring the energy balance, considering the PGA incrementally and converting the $\mathrm{Sd}_{\mathrm{pp}}$ into roof displacements, $\delta$. Based on the IDA of the building, the relation between PGA and the maximum roof displacement, $\delta$ is obtained; the values $\delta$ of this relation define the dynamic displacement pattern. Figure 9b shows the comparison between the static and dynamic displacement functions that have been obtained by using the IDA and the energy balance respectively. In this case, both displacement functions show a very good agreement.

a)
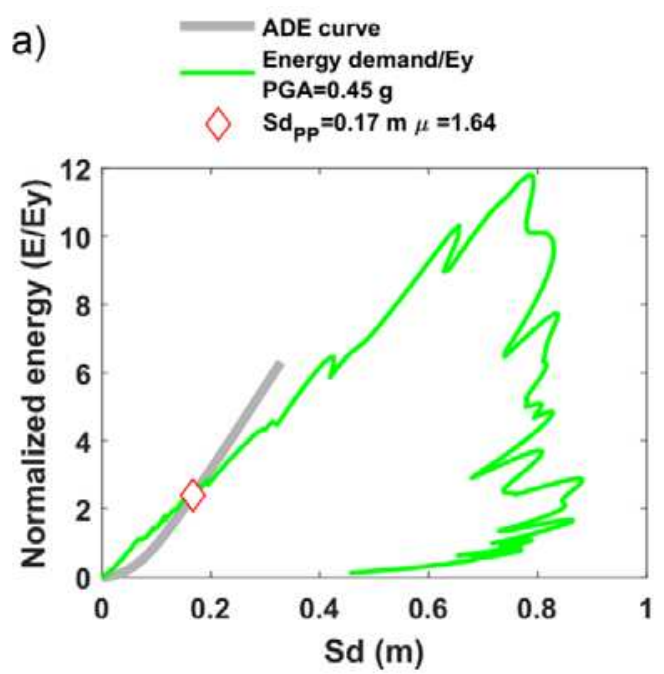

b) - Dynamic displacement functions $\square$ Static displacement functions $\diamond \delta_{\text {PP }}$ for PGA $0.45 \mathrm{~g}=0.22 \mathrm{~m}$

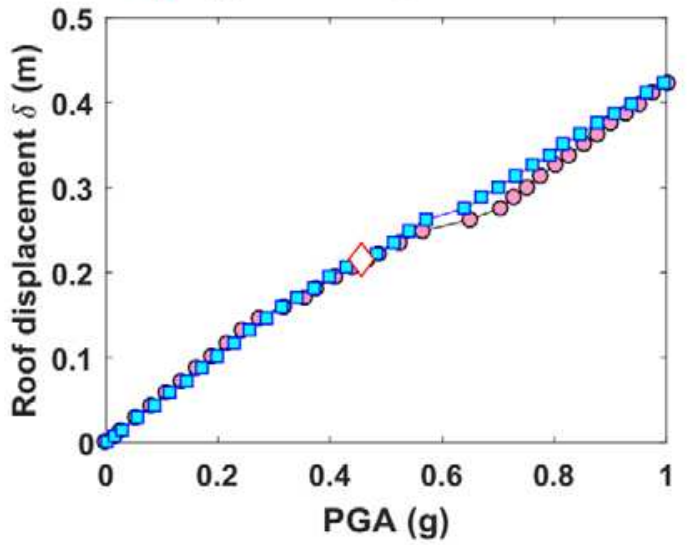

Figure 9 a) The energy balance of the building with the $\mathrm{Sa}_{\text {matched }}$ acc1 for $\mathrm{PGA}=0.45 \mathrm{~g}$; b) static and dynamic roof displacement functions.

Based on the static roof displacement function, the energy functions $\mathrm{E}_{\mathrm{so}}(\delta)_{\mathrm{NN}}$ and $\mathrm{E}_{\mathrm{D}}(\delta)_{\mathrm{NN}}$ are obtained (see Figure 10a). The $\operatorname{DI}_{\mathrm{PAw}}(\delta)$ of the building is used to calibrate the energy capacity damage index obtaining $\eta=0.70$, that 
means, the contribution to the damage index of the strain energy function, $\mathrm{E}_{\mathrm{so}}(\delta)_{\mathrm{NN}}$, is $70 \%$, while the contribution of the hysteretic dissipated energy, $\mathrm{E}_{\mathrm{D}}(\delta)_{\mathrm{NN}}$, is $30 \%$. These percentages would vary for different seismic actions.

Figure 10a shows the energy capacity damage indices $\mathrm{DI}_{\mathrm{EC}}(\delta)$ and $\mathrm{DI}_{\mathrm{PAw}}(\delta)$ for the building. Both indices show a very good agreement. Observe that the damage curves calculated can be also related to the PGA by considering the function shown in Figure 10b. This way the proposed energy capacity damage index can be directly related to an intensity measure of the earthquake. Figure $10 \mathrm{~b}$ shows the $\mathrm{E}_{\mathrm{so}}(\mathrm{PGA})_{\mathrm{NN}}$ and $\mathrm{E}_{\mathrm{D}}(\mathrm{PGA})_{\mathrm{NN}}, \mathrm{DI}_{\mathrm{PAw}}(\mathrm{PGA})$ and the $\mathrm{DI}_{\mathrm{EC}}(\mathrm{PGA})$ functions. In the case studied here, the $\mathrm{DI}_{\mathrm{EC}}(\mathrm{PGA})$ also shows a very good agreement with the $\operatorname{DI}_{\mathrm{PAw}}(\mathrm{PGA})$.
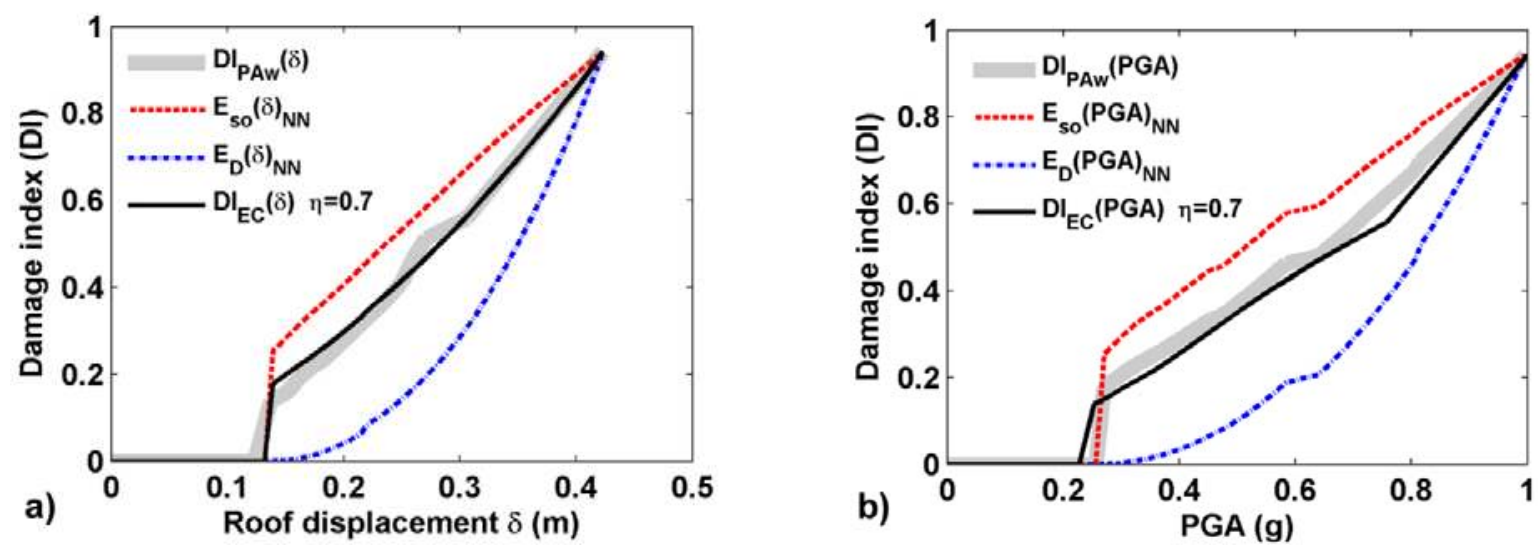

Figure 10 a) $\operatorname{DI}_{\mathrm{PAw}}(\delta)$ and $\mathrm{DI}_{\mathrm{EC}}(\delta)$; and b) $\mathrm{DI}_{\mathrm{PAw}}(\mathrm{PGA})$ and $\mathrm{DI}_{\mathrm{EC}}(\mathrm{PGA})$ of the SFM 3 building.

\section{Probabilistic approach}

The model of the studied building is used now to estimate the new damage index from a probabilistic point of view. It will be proved that the proposed damage index fits well the results obtained with the IDA also when several uncertainties are considered in the mechanical properties of the materials and in the seismic action. For the probabilistic approach, the Monte Carlo method [55,56] and the Latin Hypercube Sampling (LHS) technique $[57,58]$ are used to optimize the number of samples. The strength and ductility of the beams and columns are considered as random variables in the modified Ibarra-Medina-Krawinkler (IMK) model [37-39]. The backbone curve of the modified IMK model is defined by three strength parameters: $\mathrm{M}_{\mathrm{y}}=$ effective yield moment; $\mathrm{M}_{\mathrm{c}}=$ capping moment strength or post-yield strength ratio $\mathrm{M}_{\mathrm{c}} / \mathrm{M}_{\mathrm{y}}$ and $\mathrm{M}_{\mathrm{r}}=\mathrm{k} \cdot \mathrm{M}, \mathrm{k}=0.4$, residual moment and by four deformation parameters: $\theta_{\mathrm{y}}=$ yield rotation; $\theta_{\mathrm{p}}=$ pre-capping plastic rotation for monotonic loading (difference between yield rotation and rotation at maximum moment); $\theta_{\mathrm{pc}}=$ post-capping plastic rotation (difference between rotation at maximum moment and rotation at complete loss of strength); and $\theta_{u}=$ ultimate rotation capacity (see Figure 11a). The strength parameters can be determined for W sections according to Lignos and Krawinkler [38,39] and from the recommendations of PEER/ATC 72-1[43] using the following equations: 


$$
\begin{gathered}
\mathrm{M}_{\mathrm{y}}=1.17 \cdot \mathrm{Z} \cdot \mathrm{f}_{\mathrm{y}} \\
\mathrm{M}_{\mathrm{c}}=1.11 \cdot \mathrm{M}_{\mathrm{y}} \\
\mathrm{M}_{\mathrm{r}}=0.4 \cdot \mathrm{M}_{\mathrm{y}}
\end{gathered}
$$

The deformation parameters can be determined for $\mathrm{W}$ sections by means of the following multi-variable empirical equations, that were developed by Lignos and Krawinkler $[38,39]$ and included in the PEER/ATC 72-1[43].

$$
\begin{gathered}
\theta_{\mathrm{y}}=\left(\mathrm{M}_{\mathrm{y}} / \mathrm{k}_{\mathrm{o}}\right) / \mathrm{L}=\left(1.17 \cdot \mathrm{Z} \cdot \mathrm{f}_{\mathrm{y}} / 6 \cdot \mathrm{E} \cdot \mathrm{I}\right) / \mathrm{L} \\
\theta_{\mathrm{p}}=0.0865 \cdot\left(\frac{\mathrm{h}}{\mathrm{t}_{\mathrm{w}}}\right)^{-0.365} \cdot\left(\frac{\mathrm{b}_{\mathrm{f}}}{2 \cdot \mathrm{t}_{\mathrm{f}}}\right)^{-0.140} \cdot\left(\frac{\mathrm{L}}{\mathrm{d}}\right)^{0.340} \cdot\left(\frac{\mathrm{c}_{\text {unit }}^{1} \cdot \mathrm{d}}{533}\right)^{-0.721} \cdot\left(\frac{\mathrm{c}_{\text {unit }}^{2} \cdot \mathrm{f}_{\mathrm{y}}}{355}\right)^{-0.721} \sigma_{\mathrm{In}}=0.32 \\
\theta_{\mathrm{pc}}=5.63 \cdot\left(\frac{\mathrm{h}}{\mathrm{t}_{\mathrm{w}}}\right)^{-0.565} \cdot\left(\frac{\mathrm{b}_{\mathrm{f}}}{2 \cdot \mathrm{t}_{\mathrm{f}}}\right)^{-0.800} \cdot\left(\frac{\mathrm{c}_{\text {unit }}^{1} \cdot \mathrm{d}}{533}\right)^{-0.280} \cdot\left(\frac{\mathrm{c}_{\text {unit }}^{2} \cdot \mathrm{f}_{\mathrm{y}}}{355}\right)^{-0.430} \sigma_{\text {In }}=0.25 \\
\theta_{\mathrm{u}}=1.5 \cdot\left(\theta_{\mathrm{y}}+\theta_{\mathrm{p}}\right)
\end{gathered}
$$

In these equations, $\mathrm{k}_{\mathrm{o}}$ is the initial elastic stiffness; $\mathrm{Z}$ is plastic modulus; $\mathrm{E}$ is modulus of elasticity; $\mathrm{f}_{\mathrm{y}}$ is expected yield strength; $\mathrm{I}$ is the inertia moment; $\mathrm{c}^{1}$ unit and $\mathrm{c}^{2}{ }_{\text {unit }}$ are coefficients for units conversion; $\mathrm{h} / \mathrm{t}_{\mathrm{w}}$ is the ratio between the web depth and the thickness; $\mathrm{L} / \mathrm{d}$ is the ratio between the span and the depth of the beam; $b_{f} /\left(2 \cdot t_{f}\right)$ is the width/thickness ratio of the beam flange, and $\sigma_{\text {In }}$ is the standard deviation, assuming a lognormal fit of experimental data. The PEER/ATC 72-1 (2010) recommends that, when don't have experimental results of cyclic degradation of stiffness in the structural elements, the parameters $\theta_{\mathrm{p}}$ and $\theta_{\mathrm{pc}}$ must be adapted as follows: $\theta_{\mathrm{p}}^{\prime}=0.7 \theta_{\mathrm{p}}$ y $\theta_{\mathrm{pc}}^{\prime}=0.5 \theta_{\mathrm{pc}}$, as is the case of this study.

In this research is defined in the behavior of the structural elements by mean of the modified IMK model with its respective adaptation; this model can be implemented in the Ruaumoko (Carr 2002) using the bi-linear hysteresis rule with strength reduction based on the ductility. For this are used the following equations:

$$
\begin{gathered}
\mathrm{r}=\left[\frac{\mathrm{M}_{\mathrm{c}}-\mathrm{M}_{\mathrm{y}}}{\theta_{\mathrm{p}}}\right] / \mathrm{k}_{\mathrm{o}} \\
\text { DUCT } 1=\frac{\theta_{\mathrm{y}}+\theta_{\mathrm{p}}^{\prime}}{\theta_{\mathrm{y}}} \\
\text { DUCT2 }=\frac{\theta_{\mathrm{y}}+\theta_{\mathrm{p}}^{\prime}+\left[\theta_{\mathrm{pc}}{ }^{\prime}\left(\mathrm{M}_{\mathrm{c}}-\mathrm{M}_{\mathrm{r}}\right) / \mathrm{M}_{\mathrm{c}}\right]}{\theta_{\mathrm{y}}} \\
\text { DUCT3 }=\frac{\theta_{\mathrm{y}}+\theta_{\mathrm{p}}^{\prime}+\theta_{\mathrm{pc}}}{\theta_{\mathrm{y}}}
\end{gathered}
$$

where $r$ is hardening factor as a fraction of the initial stiffness, $\mathrm{k}_{0}$; DUCT1 is the ductility at which degradation begins; DUCT2 is the ductility at which degradation stops, the strength reduction rule of the Ruaumoko indicates 
that the DUCT2, is defined based on the residual strength of the element, by mean of one constant, (RDUCT); in this research, RDUCT is defined as the constant $\mathrm{k}=0.4$ of the modified IMK model; finally, DUCT3 is the ductility at 0.01 of the initial strength (it is recommended to see the Ruaumoko manual (Carr 2002)). Thus, using equations (16) to (26), the expected behavior of the structural elements in the Ruaumoko is modeled. Figure 11a shows the model used based on the parameters of the modified IMK model and the bi-linear hysteresis rule with strength reduction based on the ductility of the Ruaumoko.

For a better representation of the physical randomness in the problem, for each structural element, a random sample of the three parameters used $\left(f_{\mathrm{y}}, \theta_{\mathrm{p}}\right.$ and $\left.\theta_{\mathrm{pc}}\right)$ is generated. Afterwards, the properties of strength and ductility of the plastic hinges of each element are estimated. It is assumed that hinges at both ends of the elements are the same. Thus, the 3 -stories model with 27 elements ( 15 columns and 12 beams) has 81 random variables. Table 2 shows the mean value $\mu$, the standard deviation, the coefficient of variation $(\mathrm{COV})$ and the assumed probability distributions of these 3 parameters.

Moreover, and to avoid unrealistic samples in LHS simulations, the normal distribution of $\mathrm{f}_{\mathrm{y}}$ and lognormal distributions of $\theta_{\mathrm{p}}$ and $\theta_{\mathrm{pc}}$ were truncated at both ends, the lower and upper limits being determined by the mean value \pm 2 standard deviations $(\mu \pm 2 \sigma)$. The purpose of this truncation is to avoid underestimates or overestimates of the capabilities of the elements with samples without physical meaning.

In summary, for this research, a simplified probabilistic approach is proposed. The method uses the modified IMK model for beams and columns and uncertainties are concentrated on the variables $f_{y}, \theta_{p}$ and $\theta_{p c}$. Thus, it is assumed that these three variables have a major influence on the linear and nonlinear structural response of buildings; besides, the use of these variables is recommended in the new codes for probabilistic seismic performance assessment of steel buildings $[43,59]$.

Another important issue concerning sampling, is the correlation among variables. Two types of correlations have been considered in this research: intra- and inter-element. The intra-element correlation is given by the relation among the three parameters simulated for the same hinge; these correlations can be derived from Eqs. (20) and (21) $[38,39]$ and they are defined in Table 3. The inter-element is defined based on the research conducted by Idota et al. [60] and Kazantzi et al. [61] on the consistency in workmanship and material quality between different steel structural W sections; an inter-element correlation of 0.65 is used herein for the same section type, and a null correlation is assumed for different sections.

Table 2- Probabilistic property of the strength and ductility random variables.

\begin{tabular}{c|c|c|c|c|c}
\hline Structural section & Type & Variable & Mean $(\boldsymbol{\mu})$ & $\begin{array}{c}\text { Standard deviation }(\boldsymbol{\sigma} \text { or } \\
\left.\boldsymbol{\sigma}_{\ln }\right)\end{array}$ & Function \\
\hline \multirow{2}{*}{ W14X68 } & Strength & $\mathrm{f}_{\mathrm{y}}$ & $375.76 \mathrm{MPa}^{*}$ & $26.68 \mathrm{MPa}\left(\mathrm{COV}=0.071^{*}\right)$ & Normal distribution \\
\cline { 2 - 6 } & Ductility & $\theta_{\mathrm{p}}$ & $0.054 \mathrm{rad}^{\star}$ & $\sigma_{\ln }=0.32^{\star}$ & Lognormal distribution \\
\hline
\end{tabular}




\begin{tabular}{c|c|c|c|c|c} 
& Ductility & $\theta_{\mathrm{pc}}$ & $0.188 \mathrm{rad}^{\star}$ & $\sigma_{\mathrm{ln}}=0.25^{\star}$ & Lognormal distribution \\
\hline \multirow{3}{*}{ W16X89 } & Strength & $\mathrm{f}_{\mathrm{y}}$ & $375.76 \mathrm{MPa}^{*}$ & $26.68 \mathrm{MPa}\left(\mathrm{COV}=0.071^{*}\right)$ & Normal distribution \\
\cline { 2 - 6 } & Ductility & $\theta_{\mathrm{p}}$ & $0.047 \mathrm{rad}^{\star}$ & $\sigma_{\mathrm{ln}}=0.32^{\star}$ & Lognormal distribution \\
\cline { 2 - 6 } & Ductility & $\theta_{\mathrm{pc}}$ & $0.210 \mathrm{rad}^{\star}$ & $\sigma_{\mathrm{ln}}=0.25^{\star}$ & Lognormal distribution \\
\hline \multirow{3}{*}{ W18X97 } & Strength & $\mathrm{f}_{\mathrm{y}}$ & $375.76 \mathrm{MPa}^{*}$ & $26.68 \mathrm{MPa}\left(\mathrm{COV}=0.071^{*}\right)$ & Normal distribution \\
\cline { 2 - 6 } & Ductility & $\theta_{\mathrm{p}}$ & $0.044 \mathrm{rad}^{\star}$ & $\sigma_{\mathrm{ln}}=0.32^{\star}$ & Lognormal distribution \\
\cline { 2 - 6 } & Ductility & $\theta_{\mathrm{pc}}$ & $0.183 \mathrm{rad}^{\star}$ & $\sigma_{\mathrm{ln}}=0.25^{\star}$ & Lognormal distribution \\
\hline
\end{tabular}

* Based on the report by Lignos \& Krawinkler [38] for statistics of material yielding strength, obtained from flanges-webs tests for steel A572 grade.

- For the steel structural W sections are determined by means of the multi-variable empirical equations (20) and (21).

Table 3-Intra-element correlation for random variables of beams and columns.

\begin{tabular}{c|c|c|c}
\hline & $\boldsymbol{f}_{\mathbf{y}}$ & $\boldsymbol{\theta}_{\mathbf{p}}$ & $\boldsymbol{\theta}_{\mathbf{p c}}$ \\
\hline $\boldsymbol{f}_{\mathbf{y}}$ & 1 & 0 & 0 \\
\hline $\boldsymbol{\theta}_{\mathbf{p}}$ & 0 & 1 & 0.69 \\
\hline $\boldsymbol{\theta}_{\mathbf{p c}}$ & 0 & 0.69 & 1 \\
\hline
\end{tabular}

In order to assess the seismic behavior of the studied building in a probabilistic environment, 200 NLSA's and 200 NLDA's were performed by using the same structural models for both the static and the dynamic analysis. Figure $11 \mathrm{~b}$ shows an example of the modified IMK model used in the 12 beams W14x68 section of the probabilistic models.
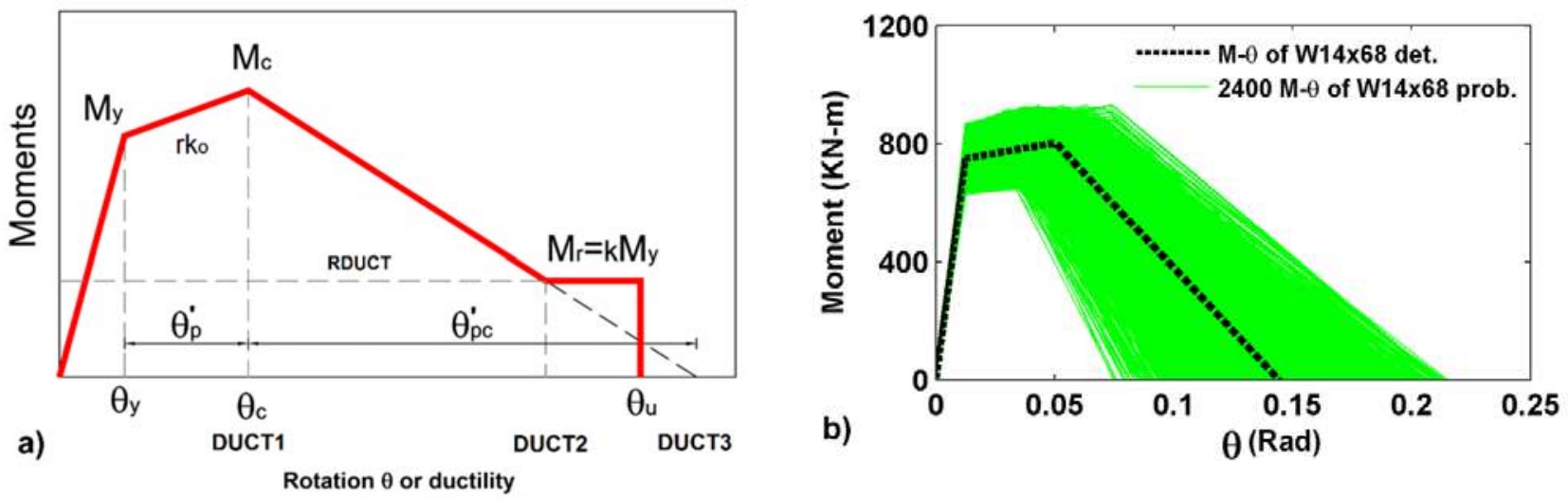

Figure 11 (a) Modified IMK model: monotonic curve; (b) an example of the modified IMK model used in the structural section (W14x68) of the probabilistic models.

The seismic action is also considered in a probabilistic way by using the set of 20 matched accelerograms developed in section 3.2 and their corresponding response spectra shown in Figure 12. It is important to note that the mean of the 20 response spectra represents correctly the target spectrum of the study area (Mexico City). Figure 12 also shows the fundamental period variation of the probabilistic models, T1 $1_{\mathrm{SFM} 3}$ prob. For each of the probabilistic IDA, one of the 20 available records is randomly selected, using a uniform probability distribution. 


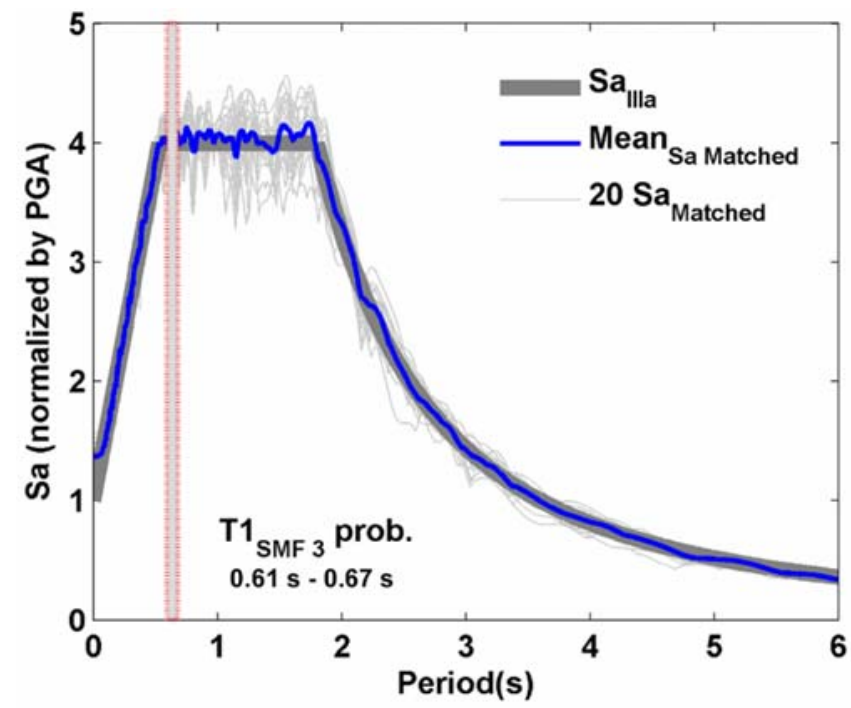

Figure 12 Response spectra of the 20 matched accelerograms and the mean spectrum. The fundamental periods of the probabilistic models are also depicted.

Figure 13a shows the probabilistic capacity curves obtained by using the procedure explained in section 3.3, and the curve representing the $50^{\text {th }}$ percentile (median) of the curves. Figure $13 \mathrm{~b}$ shows the corresponding ADE curves calculated from the capacity curves depicted in Figure 13a. Figure 14a shows the probabilistic $\operatorname{DI}_{\mathrm{PAw}}(\delta)$ and Figure $14 \mathrm{~b}$ the probabilistic $\mathrm{DI}_{\mathrm{PAw}}(\mathrm{PGA})$, both obtained with IDA analysis, in accordance with the procedure explained in section 3.4; their respective $50^{\text {th }}$ percentiles (medians) are also depicted.
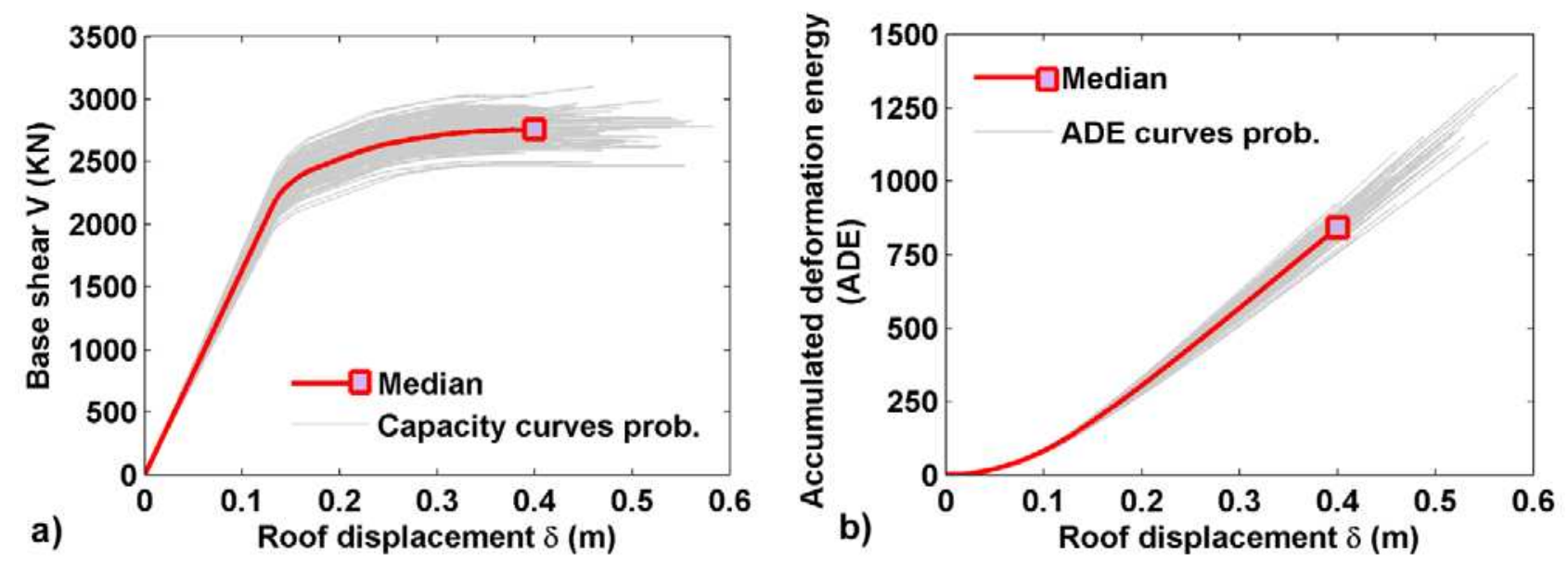

Figure 13 a) Probabilistic capacity curves and b) their respective ADE curves of the building. 

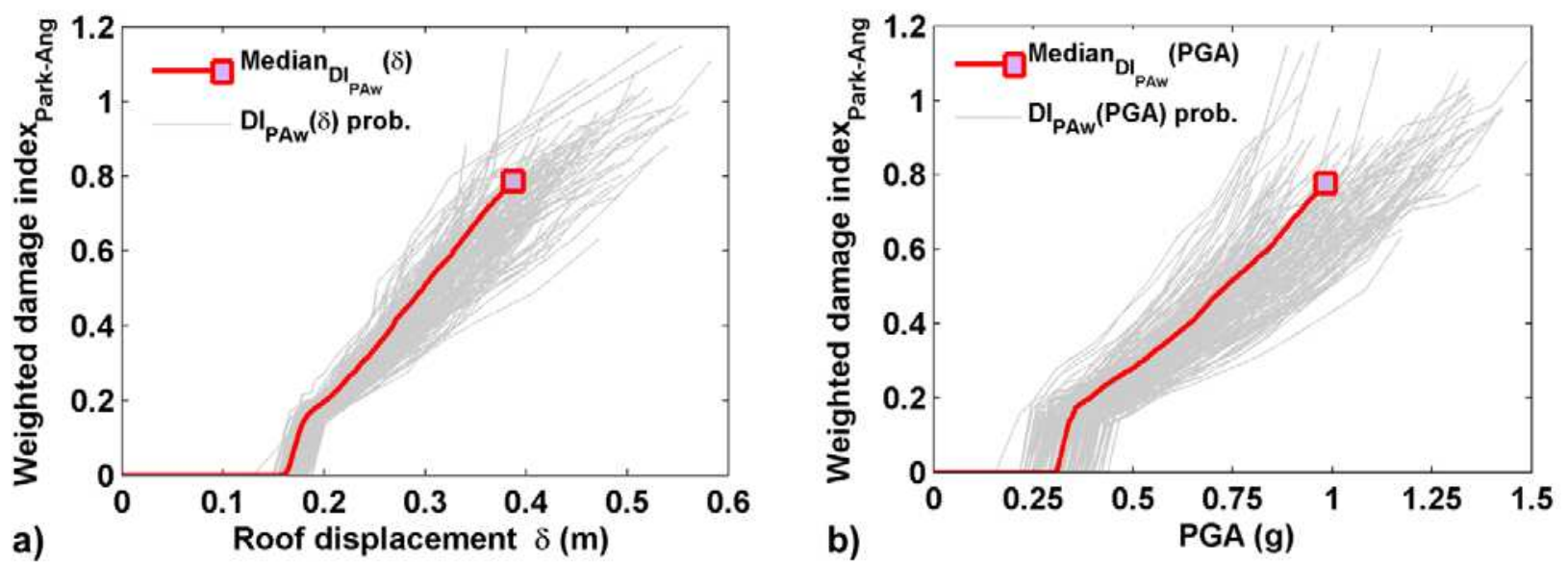

Figure 14 a) The $\operatorname{DI}_{\text {PAw }}(\delta)$ probabilistic and b) the $\mathrm{DI}_{\text {PAw }}(\mathrm{PGA})$ probabilistic.

The static displacement function of each probabilistic model are determined on the basis of the energy balance between their ADE curve and the response spectrum in EDRS format of the matched accelerogram that was used in the IDA in the same probabilistic model.

Afterwards, the energy capacity damage index, $\operatorname{DI}_{\mathrm{EC}}(\delta)$, is calculated and calibrated with the corresponding $\mathrm{DI}_{\mathrm{PAw}}(\delta)$. Figure 15a shows the obtained curves. In this figure, the $\mathrm{DI}_{\mathrm{PAw}}(\delta)$ curves calculated via IDA are shown together with the corresponding $\operatorname{DI}_{\mathrm{EC}}(\delta)$ curves. The median curves are also shown in Figure 15a. The median $\operatorname{DI}_{\mathrm{EC}}(\delta)$ curve shows a good fit to the median $\mathrm{DI}_{\mathrm{PAw}}(\delta)$ curve for a parameter $\eta=0.62$; so for probabilistic cases, it is obtained that the contribution to the $\operatorname{DI}_{\mathrm{EC}}(\delta)$ of the strain energy function, $\mathrm{E}_{\mathrm{so}}(\delta)_{\mathrm{NN}}$, is $62 \%$, while the contribution of the energy dissipated by hysteretic cycles, $\mathrm{E}_{\mathrm{D}}(\delta)_{\mathrm{NN}}$, is $38 \%$. The $\mathrm{DI}_{\mathrm{EC}}(\delta)$ can be well fitted to the $\mathrm{DI}_{\mathrm{PAw}}(\delta)$. Figure $15 \mathrm{~b}$ shows the $\mathrm{DI}_{\mathrm{PAw}}(\mathrm{PGA})$ and the $\mathrm{DI}_{\mathrm{EC}}(\mathrm{PGA})$ probabilistic functions. Again, in all the cases, a very good agreement is obtained, especially in the median value. Therefore, the new damage index can be used also for establishing appropriately the expected damage in function of the intensity of the seismic action.

Finally, it is worth to mention that the parameter $\eta$ is crucial in the energy damage index. Notice that each $\operatorname{DI} \operatorname{Paw}(\delta)$ curve is obtained for a specific seismic action. It can be expected that different seismic actions lead to different Park and Ang index values and, therefore, to different values of the parameter $\eta$. Thus, the parameter $\eta$ allows the new index, $\operatorname{DI}_{\mathrm{EC}}(\delta)$, fitting properly the response and the expected damage when the building is subjected to different seismic actions. 
a) $\mathrm{DI}_{\mathrm{PAw}}(\delta)$ prob. $-\mathrm{DI}_{\mathrm{EC}}(\delta)$ prob.

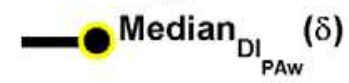

$\square^{\text {Median }_{D_{\mathrm{EC}}}(\delta) \eta=0.62}$

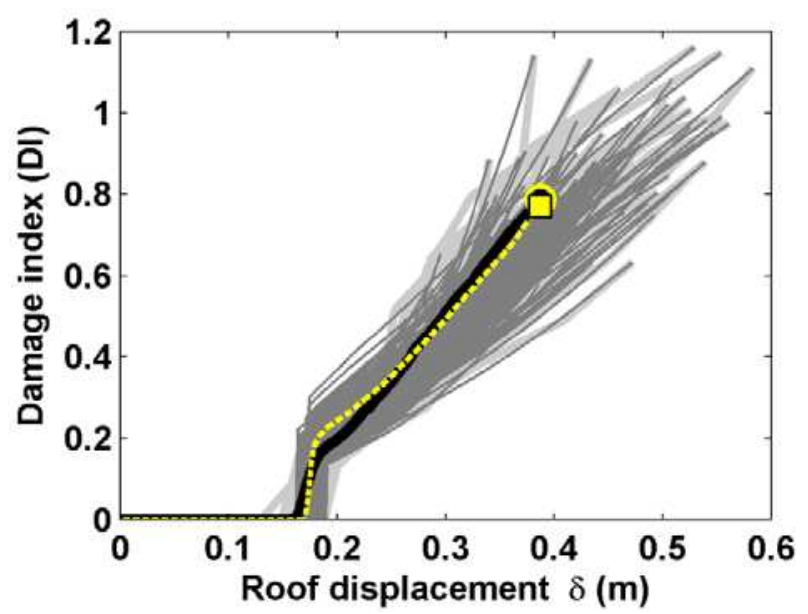

b)

$\mathrm{DI}_{\mathrm{PAw}}(\mathrm{PGA})$ prob.

DI $\mathrm{DC}_{\mathrm{C}}(\mathrm{PGA})$ prob.

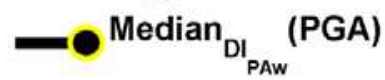

$\square^{\text {Median }_{\mathrm{DI}} \text { (PGA) } \eta=0.62}$

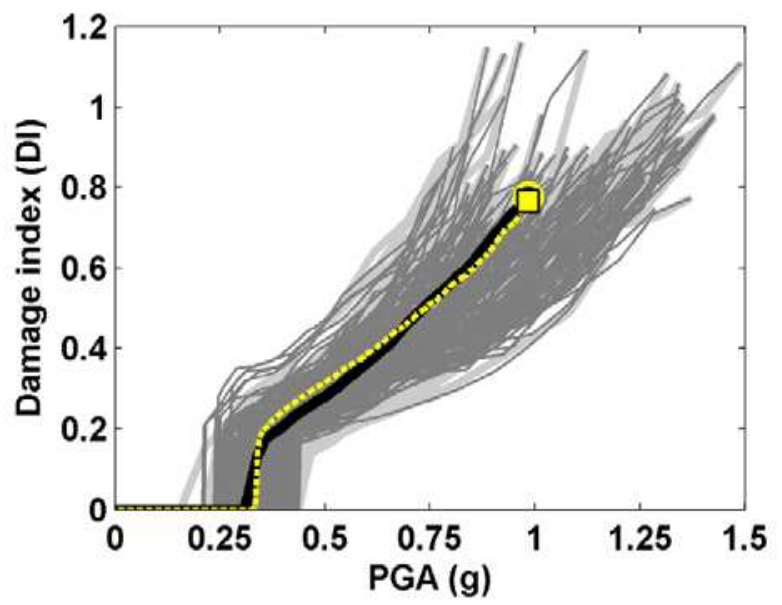

Figure 15 a) The $\operatorname{DI}_{\mathrm{PAw}}(\delta)$ and the $\mathrm{DI}_{\mathrm{EC}}(\delta)$ probabilistic, and b) the $\mathrm{DI}_{\mathrm{PAw}}(\mathrm{PGA})$ and the $\mathrm{DI}_{\mathrm{EC}}(\mathrm{PGA})$ probabilistic.

\section{Conclusions}

In this research a new damage index based on the capacity curve obtained by means of nonlinear static analysis has been developed. Two energy functions are defined. The former is the strain energy, $\mathrm{E}_{\mathrm{so}}(\delta)$, which is associated to the stiffness variation and to the ductility of the structure as well. The latter is the energy dissipated by damping, $E_{D}(\delta)$, which is related to the energy dissipated by hysteretic cycles. From a linear combination of these two energy functions by means of a parameter of contribution to damage $\eta$, the new damage index, $\operatorname{DIEC}(\delta)$, is defined. The parameter $\eta$ is calibrated by using the well-known Park and Ang damage index, $\operatorname{DI}_{\mathrm{PAw}}(\delta)$, which is obtained from IDA. Both damage indices show a good agreement. The proposed index is not intended to be better than the Park and Ang index of the IDA, but if it represents a simple and easy technique to implement to quantify the damage based on the capacity curve and the performance point, which are faster methods than the IDA.

Concerning to the damage index for the buildings and the seismic actions studied in this research, in average, the Park and Ang damage index is well fitted by the combination of $62 \%$ of the $\mathrm{E}_{\mathrm{so}}(\delta)$ function and $38 \%$ of the $\mathrm{E}_{\mathrm{D}}(\delta)$ function.

It has been observed that the energy balance method applied incrementally provides very satisfactory results for determining the static displacement pattern in the studied building to the applied seismic actions. $\mathrm{DI}_{\mathrm{EC}}(\delta)$ can be expressed in terms of the increase of PGA, $\mathrm{DI}_{\mathrm{EC}}(\mathrm{PGA})$. The $\mathrm{DI}_{\mathrm{EC}}(\mathrm{PGA})$ exhibits the great advantage of providing a scenario of the expected damage based on the characteristics of the seismic action to which the building is subjected and also a good similarity with the damage scenario obtained with IDA. 
It should be considered that the distribution parameter, $\eta$, depends on the characteristics of the seismic action; that is, it can be expected that different seismic actions lead to different $\operatorname{DI}_{\mathrm{PAw}}(\delta)$ and, therefore, to different values of the parameter $\eta$. For instance, a longer duration of the earthquake can lead to a greater contribution of the energy function linked to the hysteresis; what makes that the parameter $\eta$ be higher, when fitting the $\operatorname{DI}_{\mathrm{EC}}(\delta)$. It would be interesting to evaluate the sensitivity of the parameter $\eta$ for seismic actions with different response spectra and different earthquake durations. In addition, can be studying the relation of the parameter $\eta$ with the type of frame mechanism for different buildings, which we consider can have an influence.

As discussed, the proposed index incorporates the characteristics of the seismic action and the structure through: 1) the displacements of the performance point for the seismic action applied and 2) by the calibration parameter $\eta$, that can have values between 0 to 1 . In the first case, it will depend directly on the response spectrum used, and a seismic code spectrum of a site can be used, so that, no is necessary using an accelerogram. In the second case, this depends on the calibration with the Park y Ang index; in a probabilistic evaluation, a value that is considered adequate can be used based on the results presented here, or one deterministic case of the building can be calibrated for the different seismic actions will be using.

The most important contribution of this article is that the new damage index based on two energy functions can be obtained directly from the capacity curves in a straightforward way and that it provides adequate results for the assessment of the expected damage in buildings in function of the characteristics of the applied seismic action, such as for instance, the frequency content and duration. Therefore, it can be a useful tool to evaluate the seismic damage of buildings, especially in a probabilistic environment where the computational times can be significantly reduced.

\section{Notation}

The following symbols have used in this paper

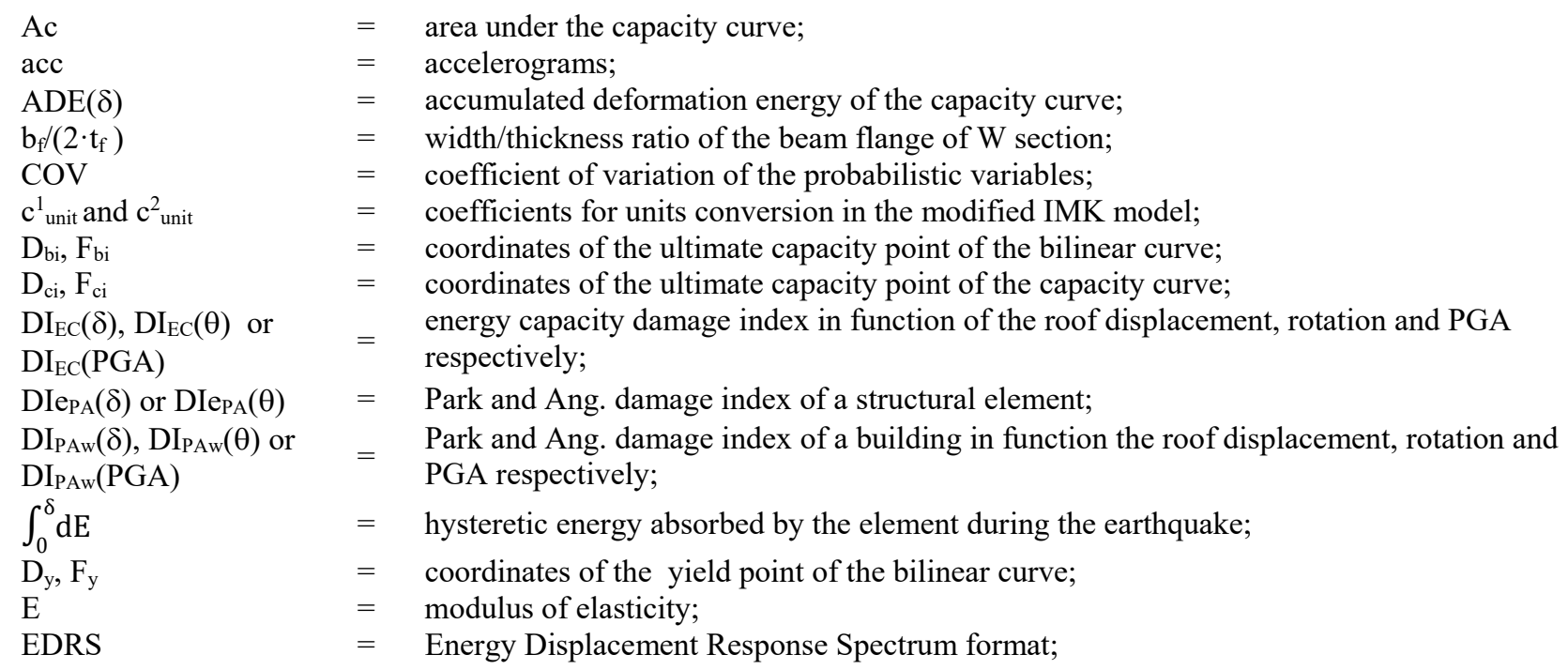


$\mathrm{E}_{\mathrm{D}}$

$\mathrm{E}_{\mathrm{D}}(\delta)$

$\mathrm{E}_{\mathrm{D}}(\delta)_{\mathrm{NN}}, \mathrm{E}_{\mathrm{D}}(\theta)_{\mathrm{NN}}$ or

$\mathrm{E}_{\mathrm{D}}(\mathrm{PGA})_{\mathrm{NN}}$

$\mathrm{E}_{\mathrm{so}}$

$\mathrm{E}_{\mathrm{so}}(\delta)$

$\mathrm{E}_{\mathrm{so}}(\delta)_{\mathrm{NN}}, \mathrm{E}_{\mathrm{so}}(\theta)_{\mathrm{NN}}$ or

$\mathrm{E}_{\mathrm{so}}(\mathrm{PGA})_{\mathrm{NN}}$

$\mathrm{E}_{\mathrm{y}}$

$\mathrm{F}(\delta)$

FR

$\mathrm{f}_{\mathrm{y}}$

$\mathrm{h} / \mathrm{t}_{\mathrm{w}}$

$i$

I

IDA

IMK

j

$\mathrm{k}$

$\mathrm{Ki}$

$\mathrm{k}_{\mathrm{o}}$

L/d

LHS

M

$\mathrm{M}_{\mathrm{c}}$

$\mathrm{M}_{\mathrm{r}}$

$\mathrm{M}_{\mathrm{w}}$

$\mathrm{M}_{\mathrm{y}}$

$\mathrm{M}^{*}$

$\mathrm{N}$

$\mathrm{n}$

NLDA

NLSA

PA

$\mathrm{P}_{\mathrm{ad}}$

$\mathrm{PF}_{1}$

PGA

$\mathrm{Qu}$

Qy

$\mathrm{R}_{\mathrm{y}}$

$\mathrm{Sa}$

SaEdRS

$\mathrm{Sa}_{\text {matched }}$

$\mathrm{Sd}_{\mathrm{pp}}$

$\mathrm{Sd}_{\mathrm{y}}$

SMF

Sv

$\mathrm{T}$

$\mathrm{T}_{\mathrm{a}}, \mathrm{T}_{\mathrm{b}}$ and $\mathrm{T}_{\mathrm{c}}$

$\mathrm{T}_{1}$

T1 $1_{\text {SFM3 }}$ prob

V

$\mathrm{V}_{\mathrm{y}}$

Z

$\beta$
$=$ energy dissipated by the structure in a single cycle of motion;

$=$ energy dissipated function;

$=\quad$ normalized energy dissipated in function of the roof displacement, rotation and PGA

respectively;

$=$ maximum strain energy associated to a cycle of motion;

$=$ strain energy function;

normalized strain energy in function of the roof displacement, rotation and PGA

respectively;

$=$ the yielding energy;

$=$ capacity curve;

$=$ connections type fully restrained;

$=$ expected yield strength;

$=$ ratio between the web depth and the thickness of $\mathrm{W}$ section;

$=$ structural element $i$

$=$ inertia moment of $\mathrm{W}$ section;

$=$ incremental dynamic analysis;

$=$ modified Ibarra-Medina-Krawinkler model;

$=$ each increment in the displacement of the capacity curve;

$=$ residual moment constant;

$=\quad$ initial slope of the capacity curve;

$=$ initial elastic stiffness;

$=$ the ratio between the span and the depth of the beam or column;

$=$ Latin Hypercube Sampling;

$=$ bending moment in the structural element;

$=$ capping moment strength or post-yield strength ratio;

$=$ residual moment;

$=$ moment magnitude scale;

$=$ effective yield moment;

$=$ effective modal mass for the first mode of vibration of the building;

$=$ number of the damaged structural elements in the building;

$=$ ultimate increment in the displacement of the capacity curve;

$=$ nonlinear dynamic analysis;

$=$ nonlinear static analysis;

$=$ Park and Ang. damage index

$=$ adaptive pushover analysis;

$=$ modal participation factor;

$=$ peak ground acceleration;

$=$ strength corresponding to the ultimate displacement;

$=\quad$ strength at the yielding point;

$=$ strength reduction factor;

$=$ acceleration spectrum;

$=$ input energy spectrum;

$=$ acceleration spectrum of the matched accelerogram;

$=$ displacement of the performance point;

$=$ yielding spectral displacement;

$=$ special moment frame building;

$=$ pseudo-velocity spectrum;

$=$ period;

$=$ limits period used to define the Ry- $\mu_{\mathrm{s}}-\mathrm{T}$ relationship;

$=$ fundamental period of the building;

$=$ the fundamental period of the probabilistic models SMF 3;

$=$ base shear;

$=$ base shear in the yielding energy;

$=$ plastic modulus;

$=$ strength deteriorating parameter in Park and Ang. damage index; 


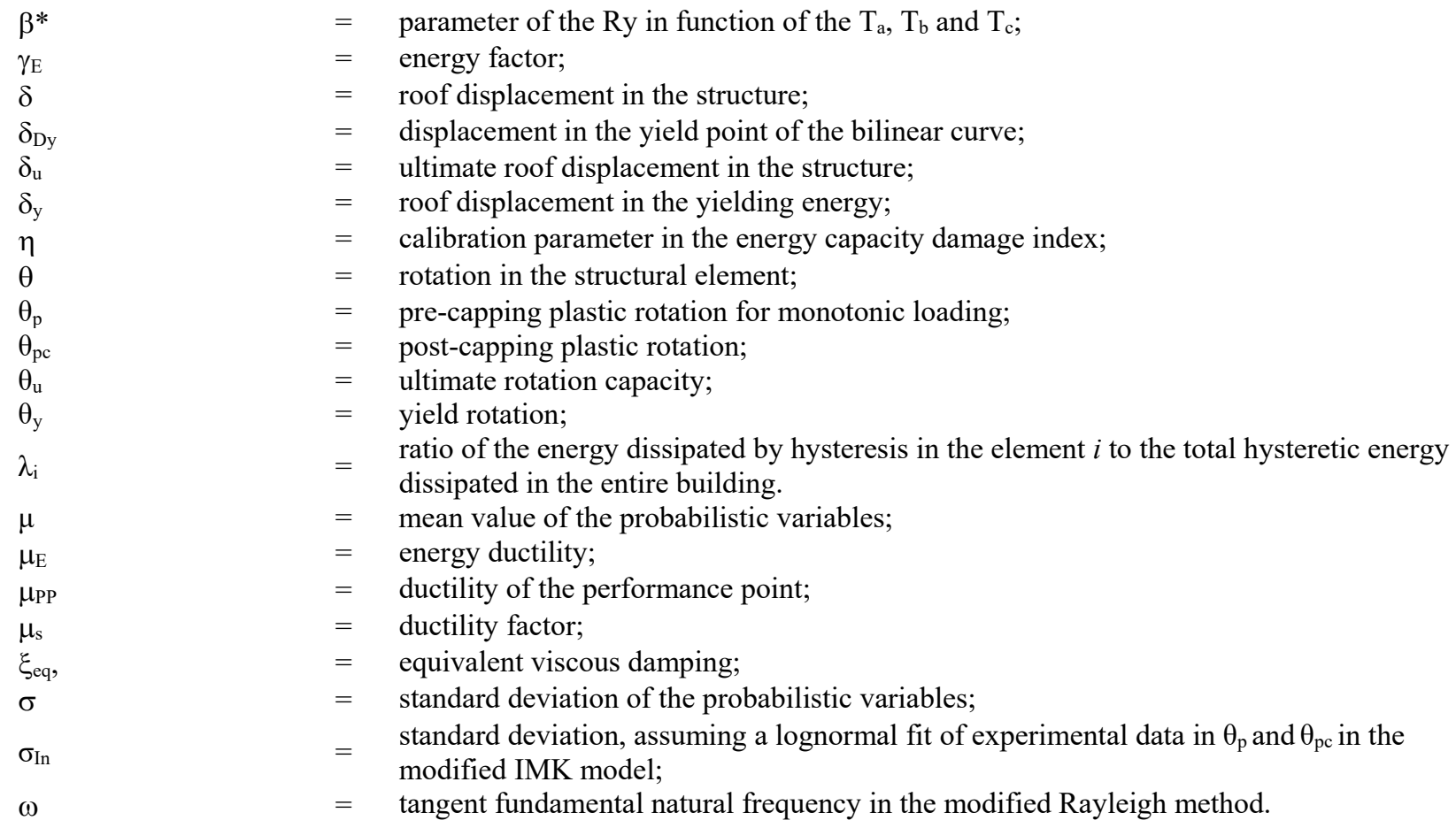

\section{Acknowledgements}

This research has been partially funded by the Ministry of Economy and Competitiveness (MINECO) of the Spanish Government and by the European Regional Development Fund (FEDER) of the European Union (UE) through projects referenced as: CGL2011-23621 and CGL2015-65913-P (MINECO/FEDER, UE). The first author holds a $\mathrm{PhD}$ fellowships from the Universidad Juárez Autónoma de Tabasco (UJAT) and from the 'Programa de Mejoramiento del Profesorado, México (PROMEP)'.

\section{References}

[1] Vamvatsikos D, Cornell CA. Incremental dynamic analysis. Earthq. Eng. Struct. Dyn. 2002; 31 (3):491-514.

[2] Carr AJ. Ruaumoko 2d y 3d Inelastic Dynamic Analysis Program (Version 2007) [Software]. University of Canterbury, Christchurch, New Zealand. 2002; http://www.civil.canterbury.ac.nz/ruaumoko

[3] Kamaris GS, Hatzigeorgiou GD, Beskos DE. A new damage index for plane steel frames exhibiting strength and stiffness degradation under seismic motion. Eng. Struct. 2013; 46:727-736.

[4] Cosenza E, Manfredi G, Ramasco R. The use of damage functionals in earthquake engineering: a comparison between different methods. Earthq. Eng. Struct. Dyn. 1993; 22:855-868.

[5] Powell GH, Allahabadi R. Seismic damage prediction by deterministic methods: Concepts and procedures. Earthq. Eng. Struct. Dyn. 1988; 16(5):719-734.

[6] Bracci JM, Reinhorn AM, Mander JB, Kunnath SK. Deterministic model for seismic damage evaluation of reinforced concrete structures. Technical Report NCEER-89-0033, National Center for Earthquake Engineering Research, State University of New York at Buffalo. 1989. 
[7] Bojorquez E, Reyes-Salazar A, Teran-Gilmore A, Ruiz SE. Energy-based damage index for steel structures. Steel Compos. Struct. 2010; 10(4):331-348.

[8] Krawinkler H, Zohrei M. Cumulative damage in steel structure subjected to earthquake ground motions. Comput. Struct. 1983; 16(1-4):531-541.

[9] DiPasquale E, Cakmak AS. Seismic damage assessment using linear models. Soil Dyn. Earthq. Eng. 1990; 9(4):194-215.

[10] Banon H, Veneziano D. Seismic safety of reinforced concrete members and structures. Earthq. Eng. Struct. Dyn. 1982; 10(2):179-193.

[11] Park YJ, Ang AH-S. Mechanistic seismic damage model for reinforced concrete. ASCE J Struct. Eng. 1985; 111(4):722-739.

[12] Roufaiel MSL, Meyer C. Analytical modeling of hysteretic behavior of R/C Frames. J. Struct. Eng. ASCE. 1987; 113(3):429-457.

[13] Bozorgnia Y, Bertero V. Improved shaking and damage parameters for post-earthquake applications. In: Proceedings, SMIP01 Seminar on Utilization of Strong-Motion Data, Los Angeles. 2001; p. 22

[14] Málaga-Chuquitaype C, Elghazouli AY. Evaluation of fatigue and Park and Ang damage indexes in steel structures. In: Proc. 15 ${ }^{\text {th }}$ World Conf. Earthq. Eng. Lisbon Portugal. 2012.

[15] Kostinakis K, Athanatopoulou A, Morfidis K. Correlation between ground motion intensity measures and seismic damage of 3D R/C buildings. Eng. Struct. 2015; 82:151-167.

[16] Vargas YF, Pujades LG, Barbat AH, Hurtado JE. Probabilistic seismic damage assessment of RC buildings based on nonlinear dynamic analysis. The Open Civil Engineering Journal. 2015; 9(Suppl. 1, M 12): 344-350.

[17] Mwafy A, Elnashai A. Static pushover versus dynamic collapse analysis of RC buildings. Eng. Struct. 2001; 23(5):407-424.

[18] Kim SP, Kurama YC. An alternative pushover analysis procedure to estimate seismic displacement demands. Eng. Struct. 2008; 30(12):3793-3807.

[19] Fragiadakis M, Vamvatsikos D. Fast performance uncertainty estimation via pushover and approximate IDA. Earthq. Eng. Struct. Dyn. 2010; 39: 683-703.

[20] Celarec D, Dolšek M. The impact of modelling uncertainties on the seismic performance assessment of reinforced concrete frame buildings. Eng. Struct. 2013; 52(1):340-354.

[21] Vargas YF, Pujades LG, Barbat AH, Hurtado JE. Capacity, fragility and damage in reinforced concrete buildings: A probabilisticapproach. Bull. Earthq. Eng. 2013; 11(6):2007-2032.

[22] Pujades LG, Vargas-Alzate YF, Barbat AH, González-Drigo JR. Parametric model for capacity curves. Bull. Earthq. Eng. 2015; 13(5):1347-1376.

[23] Barbat AH, Vargas YF, Pujades LG, Hurtado JE. Evaluación probabilista del riesgo sísmico de estructuras con base en la degradación de rigidez. Rev Int Metod Numéricos Para Cálculo Y Diseño en Ing. 2016; 32(1):3947.

[24] Lantada N, Irrizari J, Barbat AH, Goula X, Roca A, Susagna T and Pujades LG. Seismic hazard and risk scenarios for Barcelona, Spain, using the Risk-UE vulnerability index method. Bull. Earthq. Eng. 2010; 8:201229.

[25] Barbat AH, Carreño ML, Cardona OD, Marulanda MC. Evaluación holística del riesgo sísmico en zonas urbanas. Rev Int Metod Numéricos Para Cálculo Y Diseño en Ing. 2011; 27(1):3-27.

[26] Pujades LG, Barbat AH, Gonzalez-Drigo R, Avila J, Lagomarsino S. Seismic performance of a block of buildings representative of the typical construction in the Eixample district in Earthq. Eng. 2012; 10(1):331-349.

Barcelona (Spain). Bull. 
[27] Gonzalez-Drigo R, Avila-Haro J, Pujades LG, Barbat AH. Non-linear static procedures applied to high-rise residential URM buildings. Bull. Earthq. Eng. 2017; 15(1):149-174.

[28] ATC40. Seismic evaluation and retrofit of concrete buildings. Applied Technology Council. Redwood City, California. 1996; p. 346.

[29] Chopra AK, Goel RK. Capacity-demand-diagram methods based on inelastic design spectrum. Earthq. Spectra. 1999; 15(4):637 655.

[30] Housner, GW. The plastic failure of frames during earthquakes, in: 2nd World Conference on Earthquake Engineering. 1960; pp. 997-1012.

[31] Leelataviwat S, Saewon W, Goel SC. Application of energy balance concept in seismic evaluation of structures. J. Struct. Eng. ASCE. 2009; 135(2):113-121

[32] Chopra AK. Dynamics of structures: theory and applications to earthquake. Chaps. 3. Englewood Cliffs, New Jersey: Prentice Hall. 1995; p. 944.

[33] Diaz SA, Pujades LG, Barbat AH, González-Drigo JR, Hidalgo-Leiva DA. Capacity parametric model and damage index for steel buildings. A probabilistic approach. In: 16th World Conference of Earthquake Engineering (16WCEE) Santiago, Chile. 2017; paper number 0013.

[34] ANSI/AISC 358. Prequalified connections for special and intermediate steel moment frames for seismic applications. American Institute of Steel Construction. 2010; p. 178.

[35] NTC-DF. Norma técnica complementaria del Distrito Federal. Technical Report Gaceta oficial del Distrito Federal, México. Tomo I y II. 2004; p. 586.

[36] ANSI/AISC 341-10. Seismic provisions for structural steel buildings. An American National Standard and American Institute of Steel Construction. 2010; 356 pp.

[37] Ibarra LF, Medina RA, Krawinkler H. Hysteretic models that incorporate strength and stiffness deterioration. Earthq. Eng. Struct. Dyn. 2005; 34(12):1489-1511.

[38] Lignos DG, Krawinkler H. Deterioration modeling of steel components in support of collapse prediction of steel moment frames under earthquake loading. J. Struct. Eng. ASCE. 2011; 137(11):1291-1302.

[39] Lignos DG, Krawinkler H. Development and utilization of structural component databases for performancebased earthquake engineering. J. Struct. Eng. ASCE. 2013; 139(8):1382-1394.

[40] Krawinkler H. Shear design of steel frame joints. J. Struct. Eng. ASCE. 1978; 15(3):82-91.

[41] FEMA 355C. State of the art report on system performance of steel moment frames subject to earthquake ground shaking. SAC Joint Venture Partnership for the Federal Emergency Management Agency. Washington, D.C. $2000 ;$ p. 334.

[42] SAC. Analytical and field investigations of buildings affected by the Northridge earthquake of January 17, 1994. Report No. SAC-95-04, prepared by SAC Joint Venture, a partnership of SEAOC, ATC and CUREE. 1995; Available at: http://www.sacsteel.org/library/reports/sum95-04.html (last visited: 2017.02.17).

[43] PEER/ATC 72-1. Modeling and acceptance criteria for seismic design and analysis of tall buildings. Applied Technology Council and Pacific Earthquake Engineering Research Center. 2010; p. 242.

[44] Diaz SA, Pujades LG, Barbat AH, Félix JL. Efecto de la direccionalidad en la amenaza sísmica de la Ciudad de México. In: $20^{\text {th }}$ Congreso Nacional de Ingeniería Sísmica. México. Acapulco, Guerrero. 2015; ISSN: 24485721.

[45] Hancock J, Watson-Lamprey J, Abrahamson N, Bommer J, Markatis A, McCoy E, Mendis R. An improved method of matching response spectra of recorded earthquake ground motionusing wavelets. Journal of Earthquake Engineering. 2006; 10(Special issue):67-89. 
[46] Freeman SA. The capacity spectrum method as a tool for seismic design. In: Proceedings of the 11th European conference on earthquake engineering. Paris. 1998.

[47]FEMA 273. NEHRP guidelines for the seismic rehabilitation of buildings, FEMA 273; and NEHRP commentary on the guidelines for the seismic rehabilitation of buildings, FEMA 274. Washington, D.C.: Federal Emergency Management Agency. 1997; p. 435.

[48] Fajfar P. Capacity spectrum method based on inelastic demand spectra. Earthq. Eng. Struct. Dyn. 1999; 28(9):979-993.

[49] Fajfar P. A nonlinear analysis method for performance-based seismic design. Earthq. Spectra. 2000; 16(3):573-592.

[50] Newmark NM, Hall WJ. Earthquake spectra and design. Earthquake Engineering Research Institute. Berkeley, California. USA. 1982; p. 103.

[51] Vidic T, Fajfar P, Fischinger M. Consistent inelastic design spectra: strength and displacement. Earthq. Eng. Struct. Dyn. 1994; 23(5):507-521.

[52] Mezzi M, Comodini F, Lucarelli M, Parducci A, Tomassoli E. Pseudo-energy response spectra for the evaluation of the seismic response from pushover analysis. In: Proc. First European Conference on Earthquake Engineering and Seismology, Switzerland. 2006; paper number 1183.

[53] Leelataviwat S, Saewon W, Goel SC. An energy based method for seismic evaluation of structures. In: Proceedings of the $14^{\text {th }}$ World Conf. Earthq. Eng., Beijing, China. 2008.

[54] Parducci A, Comodini F, Lucarelli M, Mezzi M, Tomassoli E. Energy-based non-linear static analysis. In: Proc. First European Conference on Earthquake Engineering and Seismology. Geneva, Switzerland. 2006; paper number 1178.

[55] Hurtado JE, Barbat AH. Monte Carlo Techniques. In Computational Stochastic Mechanics. Arch Comput Methods Eng. 1998; 5(1):3-29.

[56] Rubinstein RY. Simulation and the Monte Carlo method, John Wiley. New York. 1981; p. 372.

[57] McKay MD, Conover WJ, Beckman R. A comparison of three methods for selecting values of input variables in the analysis of output from a computer code. J. Technometrics. 1979; 21(2):239-245.

[58] Vamvatsikos D. Seismic performance uncertainty estimation via IDA with progressive accelerogram-wise Latin Hypercube Sampling. J. Struct. Eng. ASCE. 2014; 140(8):1-10.

[59] FEMA P-58-1. Seismic performance assessment of buildings Vol. 1 and Vol. 2. SAC Joint Venture Partnership for the Federal Emergency Management Agency. Washington, D.C. Vol 1. 2012; p. 278.

[60] Idota H, Guan L, Yamazaki K. Statistical correlation of steel members for system reliability analysis. In: Proceedings of the $9^{\text {th }}$ international conference on structural safety and reliability (ICOSSAR). Osaka, Japan. 2009.

[61] Kazantzi AK, Vamvatsikos D, Lignos DG. Seismic performance of a steel moment-resisting frame subject to strength and ductility uncertainty. Eng. Struct. 2014; 78:69-77. 